
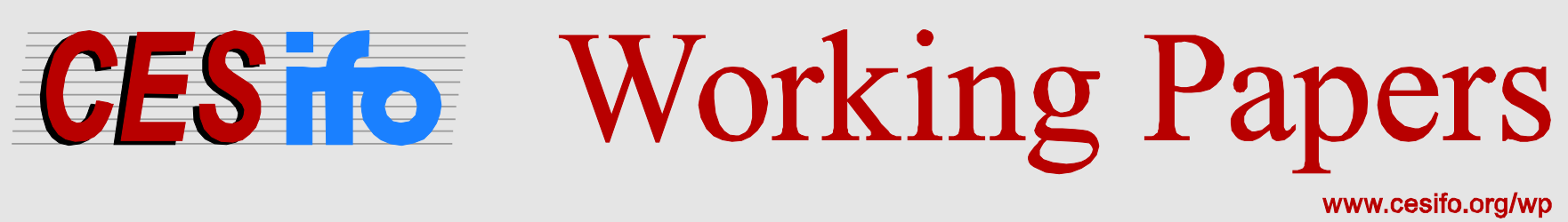

\title{
Uncertainty and the Employment Dynamics of Small and Large Businesses
}

\author{
Vivek Ghosal \\ Yang Ye
}

CESIFO WORKING PAPER NO. 5059

CATEGORY 4: LABOUR MARKETS

NOVEMBER 2014

An electronic version of the paper may be downloaded

- from the SSRN website:

- from the RePEc website:

- from the CESifo website:

WWW.SSRN.com

www.RePEc.org

www.CESifo-group.org/wp

\section{CESifo}




\title{
Uncertainty and the Employment Dynamics of Small and Large Businesses
}

\begin{abstract}
We examine the impact of uncertainty on employment dynamics. Alternative measures of uncertainty are constructed based on the survey of professional forecasters, and regressionbased forecasting models for GDP growth, inflation, S\&P500 stock price index, and fuel prices. Our results indicate that greater uncertainty has a negative impact on growth of employment, and the effects are primarily felt by the relatively smaller businesses; the impact on large businesses are generally non-existent or weaker. Our results suggest that to truly understand the effects of uncertainty on employment dynamics, we need to focus on the relatively smaller and entrepreneurial businesses. We discuss implications for the framing of economic policy.
\end{abstract}

JEL-Code: L110, D800, O300, G100, L400.

Keywords: uncertainty, employment, small businesses, entrepreneurship, real-options, financing-constraints.

\author{
Vivek Ghosal* \\ School of Economics \\ Georgia Institute of Technology \\ Atlanta / Georgia / USA \\ vivek.ghosal@econ.gatech.edu
}

\author{
Yang Ye \\ Whitman School of Management \\ Syracuse University \\ Syracuse / NY / USA \\ yye06@syr.edu
}

*corresponding author

October, 2014

We are extremely grateful to two anonymous referees and the editor for insightful and constructive suggestions that have significantly improved the paper. We are indebted to Christian Gollier and Pierre-André Chiappori for helpful comments on an earlier version of this paper, and to the seminar participants at Mizuho Research Institute (Tokyo), the Development Bank of Japan (Tokyo) and the Center for Economic Studies (Munich) for feedback. Part of this work was conducted when Vivek Ghosal was a Visiting Scholar at the Research Department of the International Monetary Fund (Washington, D.C.); I benefited from valuable discussions with Prakash Loungani, and helpful suggestions by Sangyup Sam Choi and Akito Matsumoto. 


\section{Introduction}

Theory identifies alternative channels via which uncertainty can affect firms' decisions related to capital investment outlays, entry, exit, production, R\&D expenditures and choice of technology. While the literature is quite diverse and expansive, three broad classes of theories have come to dominate the discussion. These include: real-options, where the sunk cost component of expenditures can adversely affect input and production decisions under uncertainty; information-asymmetry between lenders and borrowers which, under greater uncertainty, are likely to affect the flow of credit to specific categories of businesses and influence their choices of inputs and production; and attitudes towards risk, with greater riskaversion having the potential to affect a range of decisions. Regarding uncertainty itself, the literature has examined uncertainty arising from a wide range underlying factors such as demand, prices, input costs, cashflow, project returns, technological factors, regulatory and economic policy changes. As we discuss in the next section, the alternative theoretical channels and underlying sources of uncertainty often predict similar qualitative effects. In our review of the empirical evidence, we present an extensive survey of the literature to highlight the findings on the effects of uncertainty on decisions related to inputs, entry and exit, inventories, technology and production.

While there is a significant literature in economics, strategic management and entrepreneurship that has examined the impact of uncertainty on various aspects of firms' decisions, we are not aware of any study that has formally examined the effect on employment. In an influential contribution, Bloom, Bond and van Reenen (2007) note that: “ ... while we do not model the behavior of labor demand, the existence of labor hiring and firing costs would imply that higher uncertainty would also make employment responses to demand shocks more cautious...” A key component of the real-options models, for example, is that the expenditures incurred have a sunk cost component. In this dimension, there is an extensive literature in labor economics that has theoretically modeled and empirically examined costs related to hiring and terminating workers. This literature notes that these employment decisions entail variable and

fixed costs, some of which are sunk. Examining the link between uncertainty and employment dynamics fits well into the broader literature on uncertainty, and addresses an important aspect that has not been studied in detail. 
In addition, examining the effects of uncertainty on employment has taken on a prominent role following the 2008 economic crisis, where employment effects have taken center stage in policy debates on how to improve economic conditions. Leduc and Liu (2012), addressing policy issues, note that in the 2008 financial crisis, greater uncertainty has reduced employment and increased the unemployment rate, and the relative ineffectiveness of the standard monetary policy measures to alleviate this problem. Mishkin (2011) notes that the increase in uncertainty during the financial crisis lead to an increase in asymmetric information, which hindered the ability of financial markets to allocate funds to businesses, affecting a range of their decisions. He notes alternative policies that may equilibrate the markets. Denis and Kannan (2013) find that greater uncertainty significantly affects economic activity, depressing industrial production, GDP and employment. The Economist (2013) noted that heightened uncertainty lowers employment, as firms hold off hiring new workers. Given this, more systematic evidence on the impact of uncertainty on employment would help us better understand the underlying nature of firms' decisions and inform economic policy making.

Our specific focus is to examine the potentially differential effects of uncertainty on employment in larger versus smaller businesses. As we note in the next section, the informationasymmetries driven financing-constraints models suggest that the effects of uncertainty are more likely to be concentrated in the smaller businesses. While there is some evidence regarding the effects of uncertainty on larger versus smaller businesses in terms of capital investments, there are no studies related to employment dynamics.

Apart from relevance to some of the underlying theories, there are broader reasons to focus on smaller versus larger businesses. First, small businesses play an important role in the economy in several dimensions. According to the U.S. Small Business Administration (henceforth, SBA), small businesses represent about 99 percent of all employer firms, and employ about one-half of all private sector employees. Small businesses pay about 43 percent of total U.S. private payroll and have generated 65 percent of net new jobs over the past 18 years. Small businesses create more than half of the non-farm private GDP, made up 97 percent of all identified exporters and produced 31 percent of export value in 2008. Small businesses are also important to technology improvement. According to the SBA, small businesses hire over 40 percent of high tech workers (scientists, engineers, computer programmers, and others). Small businesses generate patents more efficiently than large firms: they produce 16 times more patents 
per employee than large patenting firms. Irrespective of the specific dimension under consideration, small businesses clearly play a vital role in the economy.

Overall, our examination of the effects of uncertainty on employment dynamics, and the potential differences between the smaller versus larger firms, contributes to the growing literature on understanding the wide-ranging effects of uncertainty. To the extent that uncertainty may significantly matter in influencing employment dynamics, and the potential differences between smaller versus larger firms, our findings would be of relevance to policy.

The paper is organized as follows. In section 2 we note some of the key theoretical results relevant to our analysis and present the hypotheses. Section 3 presents a brief overview of the empirical literature. Data sources and variables are discussed in section 4, and in section 5 we outline the construction of our measures of uncertainty. Sections 6 and 7 develop the empirical specification we estimate, and present the results. Our main findings are that uncertainty negatively affects the growth of employment and this impact appears to be concentrated primarily in the relatively smaller business category. The impact on the large business category is typically non-existent. Section 8 concludes with a discussion of our findings and some economic policy issues.

\section{Theoretical considerations}

In this section we discuss some of the main theoretical models related to real-options, information-asymmetry driven financial constraints, and risk-preferences, and note the results useful for our empirical analysis.

\subsection{Real-options}

Using the real-options framework, McDonald and Siegal (1986) provided deep insights into firms' investment behavior under uncertainty. Their contribution generated a large literature that has examined the impact of uncertainty on important decision variables such as investment, entry and exit, R\&D, technology choices, production, start-up and shut-down decisions of production facilities and mines, among others. The literature is expansive and the core theoretical contributions rely on complex mathematical modeling and computational procedures to provide qualitative and quantitative insights. As these results are well known, below we briefly highlight them and note the links to our empirical analysis. 
In the core set of theoretical contributions by McDonald and Siegal (1986), Dixit (1989) and Dixit and Pindyck (1994), uncertainty and sunk costs imply an option-value of waiting and are likely to depress investment and entry. In Dixit (1989) and Dixit and Pindyck (1994), the standard analysis pertains to a situation where they assume that costs remain unchanged but market demand fluctuates. Therefore, uncertainty about payoffs arises from the demand-side. ${ }^{3}$ Related to demand uncertainty, the numerical simulation results in Dixit (1989) and Dixit and Pindyck (1994) show that even small amounts of uncertainty are sufficient to generate considerable hysteresis and depress investment and entry.

Considering a different source of uncertainty, Pindyck (1993) examines costs. He considers two sources of cost uncertainty: (i) input cost uncertainty, which arises from factor prices of labor, materials and other inputs, as well as regulatory interventions (e.g., safety, environmental, etc.) that may be important for specific industries; and (ii) technical uncertainty, which he describes as uncertainty over factors such as the materials that may be required to complete a project, R\&D projects, time to build, effort, among others. He notes that this kind of uncertainty can only be resolved by undertaking and completing the project. In Pindyck's model, the firm's optimal capital stock is a function of both technical and input cost uncertainty. The simulation results in Pindyck show that while the optimal capital stock decreases with input cost uncertainty, it increases with technical uncertainty. ${ }^{4}$ The results show that the optimal capital is far more sensitive to input cost uncertainty, making this the dominant effect in general. ${ }^{5}$

In summary, examining uncertainty driven by input costs, Pindyck (1993) finds that the ‘qualitative’ results are similar to those obtained under demand uncertainty (Dixit, 1989; and Dixit and Pindyck 1994): investment will decrease under greater uncertainty, and is highly sensitive to them.

In other models under the real-options rubric, and examining R\&D investments and technology choices, Kulatilaka and Perotti (1998), Folta and O’Brien (2004), Oriani (2007) and Oriani and Sobrero (2008), for example, show that uncertainty about demand or technological

\footnotetext{
${ }^{3}$ Dixit and Pindyck (1995) present an excellent non-technical exposition of the option value approach. Additional results on the effects of uncertainty via the real-options channel are noted in Abel at. al. (1996).

${ }^{4}$ These are presented in figures 1 and 3 for the base cases, and tables 1 and 2 for the general cases.

${ }^{5}$ The class of models considered above require an extensive set of complex mathematical and computational assumptions, and it is very hard to obtain closed-firm solutions, hence these papers resort to numerical simulations to shed light on the quantitative importance of the effects.
} 
factors have different effects on options to wait, grow, or switch. Under demand uncertainty, firms have to consider the option to wait or acquire a growth option, and there emerges a Ushaped relation between demand uncertainty and R\&D investment. With technological uncertainty, which relates to uncertainty about frontier technologies that may emerge in future periods, firms have to consider waiting for the technology to evolve before committing, or devote incremental resources to $R \& D$ to create an option to switch. There emerges an inverted-U shaped relationship between technological uncertainty and R\&D investments.

Returning to the framework developed by McDonald and Siegal, Dixit, and Dixit and Pindyck, the two key elements are uncertainty and the presence of some sunk costs in the expenditures incurred by the firm. While they do not explicitly solve the employment problem, there are direct implications. In an influential recent contribution, Bloom, Bond and van Reenen (2007) note that:

“... fluctuations in uncertainty can play an economically important role in shaping investment decisions... while we do not model the behavior of labor demand, the existence of labor hiring and firing costs would imply that higher uncertainty would also make employment responses to demand shocks more cautious..."

Regarding the hiring and firing costs noted above, there is an extensive literature in labor economics that has examined the costs firms face when hiring and terminating workers. The literature considers two types costs. First, is the literature that blossomed after the seminal contribution by Oi (1962) which emphasized the quasi-fixed nature of labor. The quasi-fixed nature arises from a range of costs firms have to incur such as those related to on-job training, transactions costs incurred in search, termination costs, among others. The issues are perhaps best stated by Abowd and Kramarz (2003) when they write:

“... facing economic shocks, the firm must decide to hire or to terminate some workers. To compute the optimal decision ... firms must take into account different types of costs and benefits: past hiring costs, past training costs (both of which are sunk), termination costs, total compensation, and marginal productivity..."

A second strand of this literature has focused on modeling and estimating adjustment costs when studying employment dynamics. These include important contributions by Sargent (1978), Kennan (1979), Nickell (1986), Hamermesh (1992), Hamermesh and Pfann (1996), Caballero and Engel (1993), Caballero et al. (1997), Cooper and Willis (2009) among others. 
The costs of adjusting labor are typically estimated to be high, confirming the quasi-fixed nature of the labor input.

The theoretical and empirical literature in labor economics noted above shows that hiring and firing costs include variable and fixed costs, and important components of these costs are sunk. Given that there are fixed and sunk costs associated with employment dynamics, it satisfies a central requirement of the real-options models which note that such costs play an important role in determining the effects of uncertainty.

Based on these considerations, the real-options based results for employment would be that greater uncertainty is likely to adversely affect firms' employment decisions, the essence of the above comment by Bloom, Bond and van Reenen (2007).

From the real-options channel, we have the following hypotheses:

Hypotheses 1: Greater uncertainty is generally expected to negatively affect employment. The presence of significant levels of technological uncertainty may moderate this effect.

As noted above, the theoretical literature examines uncertainty arising from a wide range of underlying factors which include demand and costs. In the spirit of this, and consistent with the empirical literature we review in the next section, we construct alternative measures of uncertainty. Finally, under the real-options channel, the inherent tendency to delay investments, employment, entry, among other strategic decisions, apply to firms of all classes. This channel does not allow a clear distinction of potential divergence in effects between small and large firms.

\subsection{Information asymmetries and financing constraints}

In a series of influential papers, Greenwald and Stiglitz (1990a, 1990b, 1992) and Greenwald, Stiglitz and Weiss (1984) examined information asymmetries and credit rationing. Greenwald and Stiglitz (1990b) provide an excellent rendition of the core issues relevant to our analysis. They demonstrate that greater uncertainty exacerbates information asymmetries between borrowers and lenders, tightens financing constraints and lowers capital outlays. The underlying variable to conceptualize uncertainty can vary: project returns, demand, costs, cashflows, etc. These are the same as the underlying drivers considered in the real-options models. Since uncertainty increases the risk of bankruptcy, firms cannot issue equity to absorb 
the risk. Those relying primarily on credit and operating outside of equity markets, find the flow of credit rationed. Delli Gatti et al. (2003) extend the framework of Greenwald and Stiglitz and develop a model in which the financial conditions of businesses affect capital investments and entry and exit. ${ }^{6}$ This literature shows that periods of greater uncertainty widens the information asymmetries, increases the likelihood of bankruptcy, exacerbates financing constraints and can affects firms' decision across a wide range of variables.

In contrast to the agency-based models noted above, Campbell and Cochrane (1999) demonstrate that greater macroeconomic uncertainty results in countercyclical variation of volatility and risk-premia. This yields a negative correlation between uncertainty and key decision variables such as investment. The credit rationing that results from this effect can be alleviated by the existence of collateral assets. In general, and as noted by Fazzari et al. (1988) and Gertler and Gilchrist (1994), among others, smaller business are far less likely to be in a position to offer meaningful collateral. On average, larger businesses which tend to be older and more established, are in a position to offer significant collateral. This implies that the effect identified by Cochrane and Campbell will, on average, manifest itself more for smaller businesses.

Consistent with our discussion of employment dynamics in section 2.1, we note that if an increase in uncertainty enhances financing constraints, employment decisions are likely to be adversely affected. The spirit of the arguments are the same: if uncertainty affects the range of decisions related to capital, production, and entry and exit, then employment will be affected, and the direction of the effects will be similar.

The literature points to not all businesses being equally affected by potential credit market imperfections. In different strands of this literature, the papers by Audretsch and Elston (1997), Evans and Jovanovic (1989), Fazzari, Hubbard and Petersen (1988), Lensink, Bo and Sterken (2001), Ghosal and Loungani (2000), Himmelberg and Petersen (1994) and Winker (1999), for example, offer insights on the differential effects on smaller versus larger businesses. $\mathrm{Li}$ (2008) shows the differential effects of project-specific uncertainty on venture capital investment. Gertler and Gilchrist (1994) strongly emphasize the negative impact of information asymmetric and credit constraints on smaller firms. Gertler and Gilchrist note (p.314) that:

\footnotetext{
${ }^{6}$ Lensink, Bo and Sterken (2001) provide a lucid discussion of credit market conditions in the general context of investment behavior, including the roles played by uncertainty and sunk costs.
} 
“...while size per se may not be a direct determinant, it is strongly correlated with the primitive factors that do matter. The informational frictions that add to the costs of external finance apply mainly to younger firms, firms with a high degree of idiosyncratic risk, and firms that are not collateralized. These are, on average, smaller firms."

From this literature, the prediction is that greater uncertainty via the asymmetricinformation driven financing-constraints channel is likely to have a dampening effect on employment, and this effect will primarily manifest itself for the small businesses. Larger businesses due to their greater collateral, longevity in the industry and better access to financial markets will be less affected. In contrast to the real-options channel discussed in section 2.1, these models deliver clear predictions related to small versus large business effects.

From the asymmetric-information driven financing-constraints channel, we have the following hypotheses:

Hypothesis 2: Greater uncertainty is expected to negatively affect employment, and this effect is likely to be more pronounced for smaller businesses.

\subsection{Risk-preferences}

In the classical models of firms' decision-making under product price or input price uncertainty - e.g., the risk-aversion related results in Sandmo (1971), Hartman (1972, 1973, 1976) - the assumption of risk-aversion resulted in firms choosing to produce lower output and altering the input-mix. In empirical examination of these models, Ghosal $(1991,1995)$ finds that greater uncertainty alters the input-mix and results in lower capital-labor ratios. In spirit, this more traditional risk-aversion based models tend to produce observationally equivalent outcomes to the more contemporary literature which indicates that greater uncertainty may adversely affect a wide range of firms' inputs and production.

In a different strand of the risk-preferences literature, Kahneman and Tversky's (1979) prospect theory has been used to analyze decision-making under risk and the risk-return tradeoff. This literature shows a more complex relationship. The traditional wisdom is that risk and return are positively correlated. But Bowman $(1980,1982)$ noted a negative risk-return association within some industries. One of the results in this broader literature is that agents do not have uniform risk-preferences but may pursue a mixed strategy of risk-seeking and risk-averse behavior depending on the level of returns (Fiegenbaum and Thomas, 1988; Abdellaoui et. al., 
2007; Levy and Levy, 2002). There are rather complex aspects of decision-making that emerge from this theory. Individuals are likely to behave differently in face of potential loss versus potential gain. Losses hurt more than gains feel good. There is a higher weight placed on the low

probability extreme events, rather than to an overweighting all small probability events. Overall, the prospect theory line of reasoning is in contrast to the more linear relationship between uniform risk-preferences and decision-making.

In terms of predictions on behavior under uncertainty, if the world were best described as in the classical models of uniform risk-preferences, then more risk-averse behavior would likely lead to slowdown in economic activity: essentially all important aspects of firms' choices related to production and inputs would show a negative effect. However, the results from prospect theory complicate this one-dimensional relationship: if economic agents in fact altered their behavior depending on the specific state of nature (such as low versus high returns), then the relationship is more complex. Overall, under the broad set of models focusing on riskpreferences and aversion, it appears difficult to generate clear predictions on the effects of uncertainty.

From this literature, we have the following hypotheses:

Hypothesis 3: Under the more classical and uniform risk-aversion assumption, greater uncertainty is expected to negatively affect employment. However, if risk-preferences are non-linear, then no clear prediction emerges.

\section{Empirical evidence}

The empirical literature examining the effects of uncertainty is quite extensive and it is difficult and space-consuming to review the full spectrum of estimation results. To offer a perspective in a convenient format, we present a table in Appendix A which summarizes a wide range of papers. The list is not meant to be comprehensive, but display the range of variables that have used to measure uncertainty (e.g., GDP, inflation rate, prices, input costs, energy prices, stock indices, among others), the specific statistical constructs used to capture uncertainty (e.g., unconditional variance, conditional variance derived from forecasting regressions, survey measures), the level of aggregation of the studies (firm or industry level, and macroeconomic), and estimated qualitative and quantitative effects. In addition, this literature has examined the effects of uncertainty on a wide range of decision variables, such as production, investment, 
R\&D, inventories, entry and exit, plant openings and closings, among others. To conserve space, we do not repeat the range of findings here. The papers noted in the appendix summary table shed light on these.

A key issue in our analysis relates to potential differences between the relatively smaller and larger businesses. Below we briefly comment on selected papers in the literature that provide insights in this dimension.

On the potential differences on the effects of uncertainty on relatively small and large firms, most of the information comes from estimating the impact of uncertainty on investment. Using industry-level data, Ghosal and Loungani (2000) find that uncertainty negatively affects investment spending, and the negative impact is greater in industries dominated by smaller firms. Lensink et al. (2005) find that uncertainty has a negative impact on the size of investment, no matter what the type of investment is used, and that smaller firms have a lower probability of investing if uncertainty increases. Ghosal (1991) finds that uncertainty negatively affects firms' input-mix as measured by the capital-labor ratio, and that larger firms' input-mix appears less affected by uncertainty. Bianco et al. (2012) find that small family firms' investments are significantly more negatively affected by uncertainty than the relatively larger and less financially constrained non-family firms. Findings in Ghosal and Loungani (1996) reveal that uncertainty has a negative impact on investment, and the effect appears to be concentrated in those industries that are relatively competitive and atomistic in structure. Examining smaller entrepreneurial businesses, $\mathrm{Li}$ (2008) finds that market uncertainty encourages venture capital firms to delay investing, whereas competition and agency concerns prompt venture capital firms to invest sooner. Using data on venture capital investments, Li and Mahoney (2011) find that venture capitalists tend to defer new investment projects in target industries with substantial market volatility. Their examination of the effects of uncertainty on venture capital funding is important as smaller entrepreneurial businesses are often highly credit constrained from traditional sources, and have to rely on own cash-flows or venture funding (Baldwin, Gellatly and Gaudreault, 2002).

Overall, these studies appear to indicate that uncertainty may differentially affect the relatively smaller and larger firms. While these studies do not shed clear light on the underlying factors that cause the effect to be different, some of the results noted above appear to suggest that information-asymmetries related financing-constraints may be an important influence. 


\section{Data description}

For our empirical analysis, we use data from multiple sources. Below we provide details of the datasets we use.

First, is the U.S. Small Business Administration (henceforth, SBA) database. This database contains annual data on various economic and business variables by 'size of businesses' typically over the period 1988 to 2011. The data are not at the firm-or-industry level, but aggregated and then presented by alternative size classes. For example, the data on employment are available as an aggregated annual time-series for all businesses in the U.S. over 1988-2011. The aggregate employment data are then presented by firm size classes, where, based on standard U.S. Census classifications, size is based on the number of employees. For example, annual time-series data are available for employment in business with more than 500 employees, and other size classes. We discuss some of the size classes below. While the SBA data are not designed to examine firm-or-industry-specific issues, they are very useful in gauging an economy-wide picture and with a focus on firm size. For our study, the SBA data allow us to examine how uncertainty may affect employment and by different firm-size classes. From the SBA database we use annual data on employment by the size of businesses. Data by business size classification are not available prior to 1988 .

Second, we use several U.S. macroeconomic data series. Data on real GDP and GDP implicit price deflator are from the Federal Reserve Economic Data. The data on S\&P 500 stock price index are from Yahoo Finance. And data on fuel price index are from the U.S. Bureau of Labor Statistics (BLS); the fuel price index contains information on a broad range of the most commonly used fuels by producers, such as gasoline, electricity, natural gas, heating oil, among others.

Next we use the following size classifications to examine the potential smaller versus larger business effects:

1. 'All' businesses;

2. 'Large' businesses - these are businesses with $\geq 500$ employees;

3. 'Small' businesses - these are businesses with $<500$ employees; and

4. 'Smaller' businesses - these are businesses with $<20$ employees. 
The 500 employee cutoff is the standard one used by the U.S. SBA, and we use this as the baseline. We consider an additional cutoff of $<20$ employees for the following reasons: (a) a 500 employee firm is relatively large, so we wanted to consider an alternate cutoff for defining small; (b) data with the $<20$ employee cutoff was available consistently for both our variables (employment and number of businesses); and (c) a large percentage of the truly small business fall in this category.

In our estimation of employment specifications, we present estimates for each of the four groupings (1-4) noted above. In Figure 1 we display the time paths for the growth of employment by our size classes. Table 1 presents the summary statistics.

\section{Measuring uncertainty}

The review of theory in section 2 noted that uncertainty about future payoffs could arise from a wide range of factors related to demand (Dixit, 1989; Dixit and Pindyck, 1994), input costs (Pindyck, 1993), and project related technical factors (Pindyck, 1993). Pindyck (1993) and Dixit and Pindyck $(1993,1994)$ also note other factors that may generate uncertainty, such as regulatory and policy interventions.

Our data are U.S.-wide and include all relatively smaller and larger businesses. Since the data and analysis are designed to portray a broader macroeconomic picture, our alternative measures of uncertainty are also created using macroeconomic indicators. Some of our measures are designed to capture overall uncertainty about macroeconomic conditions, whereas other measures are designed to capture uncertainty arising from the cost side. Further, we noted in section 3, various papers in the literature have used a range of variables to measure uncertainty (GDP, inflation, prices, energy prices, stock prices, survey opinions, among others), and the specific statistical constructs to capture uncertainty (unconditional variance, conditional variance derived from regression estimates, survey forecast variance). Appendix A summarized some of the studies in a compact form. This expansive literature reveals a wide range of variables and methods to measure uncertainty. In the spirit of this broader literature, we use two alternative 
conceptual frameworks and six different variables to measure uncertainty. As we note below, our specific measures are consistent with those that have been used in the literature before. ${ }^{7}$

First, we use the forecasts from the Survey of Professional Forecasters (henceforth, SPF) provided by the Federal Reserve Bank of Philadelphia. These survey forecasts have been widely used in economic and business analysis, and in academic and policy arenas. The SPF asks professional forecasters to provide their forecast for key macroeconomic variables, including GDP growth, industrial production, inflation, and unemployment, among others. The forecasters provide quarterly and annual forecasts for the current year and the following year. The respondents are asked to attach a probability to each of a number of pre-assigned intervals over which their forecast may fall. The Philadelphia Fed then takes the mean probabilities over the individual respondents and reports them in the SPF release in the form of a histogram. From the Philadelphia Fed survey data we use forecasts for growth of GDP and industrial production to construct two measures of uncertainty. We use GDP growth as it is the broadest measure of economic activity. We use growth of industrial production as an alternative measure as it is the most cyclical component of the economy, and is used by many forecasters as a leading indicator of macroeconomic conditions. Our measures of uncertainty are constructed as the within-year variance of survey forecasts for growth of GDP and industrial production. This procedure is common in the literature: see for example the discussion in Lensink, Bo and Sterken (2001, p.104-105). Our two survey-based measures of uncertainty are labeled as $\sigma_{s p f g d p, t}^{2}$ and $\sigma_{s p f i n d, t}^{2}$, with spf denoting 'survey of professional forecasters' ${ }^{8}$ Both these measures indicate the uncertainty about macroeconomic conditions.

Second, we use a regression-based forecasting framework to construct alternative measures of macroeconomic uncertainty. We use the following procedure. First, we assume that the representative firm uses a forecasting specification to predict future values of the relevant variable, such as GDP growth, inflation rate, growth of fuel prices and growth of S\&P 500 stock

\footnotetext{
${ }^{7}$ Issues related to uncertainty arising from industry-or-firm specific demand, cost, regulatory and other aspects can be addressed using micro datasets. As we have stated earlier, this is not the focus of our more economy-wide analysis as the data from the U.S. Small Business Administration are aggregate.

${ }^{8}$ In a complementary literature, some differentiate between uncertainty v. disagreement. Compare two contexts: experts agree that there is a lot of uncertainty on the future growth rate; experts are confident about their estimation of future growth, but these estimations are very heterogeneous. Gollier and Zeckhauser (2005) demonstrate the effect of disagreement on the aggregate risk premium. While distinguishing between the effects of uncertainty v. disagreement on firms' decision variables is a useful exercise, we do not explore the implications of this in the current paper.
} 
index. Since our SBA data on businesses are U.S.-wide, our uncertainty measures are also created using economy-wide variables. Second, from the estimated forecasting specification, the predicted values represent the forecastable component and the residuals the unpredictable, or unforecastable, component. The variance of the forecast error (the unpredictable component) measures uncertainty. Using the residuals from forecasting equations and using the conditionalvariance to construct uncertainty measures is common. Lensink, Bo and Sterken (2001, p.99105), for example, present an excellent overview of this literature and alternative frameworks that have been used in the literature for measuring uncertainty.

To estimate the forecasting specification for the macroeconomic variables, we use available data on each variable from 1960 to 2011. The BLS fuel price indices are only available starting 1960. Given this we use 1960 as the starting year for which all of our macroeconomic variables. The terminal period is 2011, which is the same as the last period for which the U.S. SBA data were available when we started the paper. Even though the SBA data on the small and large business categories are available for the period 1988-2011, the rationale for using a longer time period to estimate the forecasting equation is as follows. An important objective is to first obtain a reliable forecasting equation with precisely estimated parameters. This is better done with a longer time-series data. This ensures that the forecasting errors we recover are not an artifact of poorly estimated forecasting equation parameters, and therefore generates better measures of uncertainty. As noted in Lensink at al. (2001), and several of the papers in the table presented in the Appendix, this framework is common. Even in the more advanced classes of time-series forecasting models, such as ARCH and GARCH which are used typically when higher frequency and longer time series are available, the core forecasting regression is estimated over a long time period, and then the errors are recovered to model uncertainty.

Based on these considerations, our approach below is consistent with several papers in the literature, and presents an alternative framework for measuring uncertainty. Next, we turn to discussing the specific variables and constructing the measures of uncertainty.

The specific variables we use to construct the measures of uncertainty are consistent with those in the literature. They are:

1. Real GDP growth. GDP indicates the overall state of the economy capturing demand and supply side effects. This measure therefore captures uncertainty about economy-wide 
conditions. Uncertainty measures based on GDP growth, in different forms, have been used by, for example, Driver et al. (2005), Asteriou et al. (2005) and Bloom (2009);

2. Inflation rate. We measure inflation as the annual percentage growth of the GDP deflator. Inflation uncertainty captures effects related to input and product prices, as well as affecting firms' real borrowing rates. Inflation uncertainty, therefore, primarily captures uncertainty arising from the cost side. The inflation rate has been used to construct measures of uncertainty by, for example, Huizinga (1993), Fountas et al. (2006) and Elder (2004);

3. Stock prices. We use the S\&P500 stock price index. As with real GDP, this is an indicator of the overall state of the economy, and forward looking indicator of investor and business confidence. This captures broader uncertainty about market conditions. Stock prices have been used to construct measures of uncertainty by, for example, Bloom (2009), Chen et al. (2011), Bloom et al. (2007), Greasley et al. (2006), and Stein et al. (2010); and

4. Real fuel price growth. We use the Bureau of Labor Statistics price index of a range of commonly used fuels by businesses. The nominal fuel price index is converted to real values after deflating by the implicit GDP deflator. This variable serves to proxy a critical input - fuels and energy - price for businesses. Fuel price uncertainty captures uncertainty arising from the input-cost side. Fuel and energy prices have been used to construct uncertainty measures by, for example, Koetse et al. (2006), Kilian (2008) and Guo et al. (2005).

Our first task is to specify the forecasting model. As our baseline, we use a second-order autoregressive, AR(2), specification as the forecasting model. AR(n) models are based on the Box and Jenkins (1970) formulation for forecasting economic variables, and historically have performed well in forecasting exercises (Meese and Geweke, 1984; Marcellino, Stock and Watson, 2003).

The forecasting specification is:

(1) $Z_{t}=\alpha_{0}+\alpha_{1} Z_{t-1}+\alpha_{2} Z_{t-2}+\varepsilon_{t}$. 
Based on the discussion above, $\mathrm{Z}$ is either real GDP growth, or inflation rate, or growth of S\&P500 stock index, or growth of real fuel prices. From specification (1), the predicted values represent the forecastable component. The residuals:

(2) $\hat{\varepsilon}_{t}=Z_{t}-\left(\hat{\alpha}_{0}+\hat{\alpha}_{1} Z_{t-1}+\hat{\alpha}_{2} Z_{t-2}\right)$,

represent the unsystematic, or unforecastable, component. Since $\hat{\varepsilon}_{t}$ can be positive or negative, we use the squared value of $\hat{\varepsilon}_{t}$ as our measure of uncertainty about the relevant variable. If the forecasting specification (1) is estimated for real GDP growth, then we denote the uncertainty measure as: ${ }^{9}$

(3) $\sigma_{g d p, t}^{2}=\left(\hat{\varepsilon}_{g d p, t}\right)^{2}$.

Using this procedure for our four economy-wide variables, we obtain four measures of uncertainty and denote them as: (i) $\sigma_{g d p, t}^{2}$; (ii) $\sigma_{\text {infl,t }}^{2}$; (iii) $\sigma_{s p 500, t}^{2}$; and (iv) $\sigma_{\text {fuel,t }}^{2}$. As we noted above, our forecasting specifications are estimated using data over a longer period 1960-2011, designed to obtain precisely estimated parameters of the forecasting equation from which we recover the residuals. This implies that the generated time-series for our four measures of uncertainty $\sigma_{g d p, t}^{2}, \sigma_{i n f l, t}^{2}, \sigma_{s p 500, t}^{2}$ and $\sigma_{f u e l, t}^{2}$ are over the period 1962-2011. As we note in the next section, in the actual estimation of the effects of uncertainty we will use data on these variables only over the period 1988-2011 as the SBA data on employment by the size categories is over 1988-2011.

While we report our baseline results using an $\mathrm{AR}(2)$ specification for (1), our results are robust to including longer lag lengths and alternative specifications of the forecasting equation (1). We comment on these experiments in section 7.

Our overall approach to measuring uncertainty is consistent with the literature and automatically builds in some checks of robustness. For example:

(1) We are using two very different conceptual approaches to construct the measures of uncertainty. First, are measures based on professional survey forecasts. Second, using the Box-

\footnotetext{
${ }^{9}$ It is assumed that the expected value of the error term in equation (1) is zero.
} 
Jenkins regression-based forecasting specifications and using the variance of the unpredictable component as a measure of uncertainty. As noted in Lensink at al. (2001), and several of the range of references above, these methods are consistent with those in the literature; and (2) We use alternative variables to measure economy-wide uncertainty. These include GDP, inflation, industry production, fuel prices and stock market index. As noted in the references above, each of these variables have been used in the literature.

Collectively the above framework implies that our inferences are not dependent on a specific conceptual approach or variable used to measure uncertainty.

Table 1 presents the summary statistics for the six alternative measures of uncertainty, and table 2 presents the correlation between the alternative measures. From table 2 we note that for GDP growth, the correlation between the professional forecasters' survey-based measure of uncertainty and the forecasting-regression based measure is 0.75 . This is somewhat reassuring that even though the underlying data and procedures to construct the measure of GDP uncertainty vary considerably, there is reasonable correlation between the two.

\section{Estimating the effects of uncertainty}

There is a substantial literature on estimation of dynamic specifications related to firms' decision variables, such as investments in physical capital, employment, inventory holdings, among others. Holt et al. (1960), Sargent (1978), Kennan (1979), Hendry et al. (1983) and Jorgenson (1986), for example, present expositions of the underlying firms' optimization theory behind the econometric models. Following this literature, we use a partial-adjustment framework to structure our empirical specification. The partial-adjustment model is based on a quadratic cost-minimizing framework where firms, when making their optimal adjustment decisions related to employment or investment, aim to minimize disequilibrium and adjustment costs. The underlying models are framed in terms of a 'representative' firm, and then applied to firm, industry or macroeconomic data. 
The disequilibrium costs in these models arise due to lost revenue (and profits) from having the relevant decision variable at a sub-optimal level. For example, delayed employment or investment can lead to lost revenues and profits. The adjustment costs are incurred when the firm attempts to align the actual quantity of the decision variable to its optimal level. A firm's attempt to rapidly align its employment will result in higher adjustment costs. While higher disequilibrium costs motivate firms to adjust employment or investment faster, higher adjustment costs call for a smoother, slower, adjustment process. The actual speed of adjustment of a decision variable like employment will be the weighted-average of the two countervailing effects.

Let EMP denote employment. The partial adjustment model for a representative firm is given by: ${ }^{10}$

(4) $E M P_{t}-E M P_{t-1}=\lambda\left(E M P_{t}^{*}-E M P_{t-1}\right)$,

where $t$ denotes time, EMP ${ }^{*}$ the optimal value of EMP, and $\lambda$ the speed-of-response parameter. In (4), the actual employment adjustment $\left(E M P_{t}-E M P_{t-1}\right)$ is a fraction $\lambda$ of the 'desired' intertemporal adjustment $\left(E M P_{t}^{*}-E M P_{t-1}\right)$. High (low) values of $\lambda$ imply high (low) speed-ofresponse.

Since EMP* is private information and not observed directly by the external researcher, it is modeled as a function of relevant driving variables. The optimal EMP* is modeled as a function of: (i) its own intertemporal dynamics (captured by lagged values, the autoregressive

\footnotetext{
${ }^{10}$ As the theoretical solution for these models are well established (e.g., Holt et al. 1960; Kennan, 1979; Hendry et al., 1983; Jorgenson, 1986), we do not repeat the details and model structure here. The optimization models refer to a representative firm, and then applied to more or less disaggregated data.
} 
component), (ii) uncertainty, and (iii) expectations of macroeconomic conditions as measured by expected GDP growth, $G D P_{t}^{e}$; if expected economic conditions improve, firms will plan to adjust their employment upwards. If GDP follows an autoregressive process of order n, AR(n), then $G D P_{t}^{e}$ can be replaced by its forecasting equation ( $k$ represents the optimal lag length):

(5) $G D P_{t}^{e}=\alpha+\sum_{k} \gamma_{k} G D P_{t-k}+e_{t}$.

Combining the GDP and uncertainty measures, and suppressing the autoregressive component for convenience, we have $E M P_{t}^{*}=f\left(G D P_{t}^{e}, \sigma_{[.], t}^{2}\right)$, where $\sigma_{[.], t}^{2}$ is a measure of uncertainty (section 5). Using the expression for $G D P_{t}^{e}$ from (5) and our uncertainty measure $\sigma_{[\cdot], t}^{2}$ we get (omitting the constant and error terms for convenience):

(6) $E M P_{t}^{*}=\sum_{k} \gamma_{k} G D P_{t-k}+\sum_{m} \xi_{m} \sigma_{[.] t-m}^{2}$,

where $\mathrm{k}$ and $\mathrm{m}$ are the appropriate lag lengths.

Using (6) in (4) and rearranging the terms, the partial-adjustment model for a representative firm is:

(7) $E \dot{M} P_{t}=\alpha_{0}+\beta(L) \sigma_{[-], t}^{2}+\gamma(L) G \dot{D} P_{t}+\delta(L) E \dot{M} P_{t}+v_{t}$, 
Where $E \dot{M} P_{t}$ is growth of employment, ${ }^{11} G \dot{D} P_{t}$ is real GDP growth, $\sigma_{[-], t}^{2}$ is the measure of uncertainty measured in natural logarithms, ${ }^{12} v_{t}$ is the error term, and (L) represents the lagged operator (we discuss the optimal lag lengths below). As noted in section 5, the six alternative measures of uncertainty we use are $\sigma_{s p f g d p, t}^{2}, \sigma_{s p f i n d, t}^{2}, \sigma_{g d p, t}^{2}, \sigma_{i n f l, t}^{2}, \sigma_{s p 500, t}^{2}$ and $\sigma_{f u e l, t}^{2}$. Our experiments with lag lengths indicated: (i) for the majority of specifications only one autoregressive lag of $E \dot{M} P_{t}$ was significant, but in a few specifications two lags were significant; (ii) $G \dot{D} P_{t}$ effects were captured by current and one lag; and (iii) at most one lag of the uncertainty variable $\sigma_{[-], t}^{2}$ was significant.

As noted in section 4, the available data from the U.S. Small Business Administration are annual and cover the period 1988-2011. Therefore we estimate specification (7) over 1988$2011 .{ }^{13}$ Estimating (7) informs us about the impact of uncertainty on changes in employment, after controlling for changes in overall economic activity (GDP growth) and the dynamic intertemporal lagged structure for the included variables. ${ }^{14}$

As noted above, specification (7) is for the representative firm. In our examination of the effects of uncertainty on changes in employment, we present estimates for all businesses in the U.S. economy, as well as those segmented by the size of the business. In doing so, we are first assuming that the representative firm is similar for the entire economy and present the aggregated result. Second, we consider that the firms vary in characteristics, and the specific characteristic we focus on is firm size. Here, the representative firm is alternatively large or small and we estimate (7) for the aggregated large versus small groups. Overall, we estimate (7) for four aggregated groups noted in the data section 4: (1) All businesses; (2) Large businesses ( $\geq 500$ employees); (3) Small businesses (businesses with $<500$ employees); and (4) Smaller businesses ( $<20$ employees).

\footnotetext{
${ }^{11}$ Since we are interested in the short-term effects of uncertainty on employment, and that the underlying data on employment and GDP contain trends, we measure both of these variables in logarithmic first-differences (rate of growth), denoted by $E \dot{M} P_{t}$ and $G \dot{D} P_{t}$.

${ }^{12}$ We enter the uncertainty measure in natural logarithms as the mean values of the uncertainty variables vary enormously in size across the different measures (see table 1). Using the actual values of the uncertainty variables in the estimated regressions resulted in large numerical differences in the estimates due to pure scaling effects. Entering the uncertainty variables in natural logarithms resulted in no differences in inferences (related to the small versus large business differences) compared to entering them in levels.

${ }^{13}$ As noted earlier, our six uncertainty measures are constructed over a longer time period. We use their values over 1988-2011 in estimating specification (7).

${ }^{14}$ As we note in section 7.3, our experiments using longer lag lengths did not provide additional insights into the effects of uncertainty.
} 


\section{Estimation results}

Our estimates and related computations are presented in the following sequence. First, in tables 3.1 and 3.2 we present the estimates from specification (7); these tables inform us of the statistical significance of the effects and the qualitative inferences. Second, due to considerable differences in the mean values of variables in the estimated regressions, it is difficult to assess the 'quantitative magnitude' of the effects of uncertainty from the estimates presented in table 3.1 and 3.2. The computation of the quantitative effects are presented in tables 4.1 and 4.2; these are calculated as the effect of a one-standard-deviation increase in uncertainty on the growth of employment. Third, to show the quantitative effects computations in a compact form, table 5 presents the total quantitative effects - these numbers are systematized and aggregated from those in tables 4.1 and 4.2, and present a clear picture of the quantitative effects of uncertainty, as well as the relative effects of uncertainty versus GDP growth.

\subsection{Estimates}

\section{Uncertainty and growth of employment}

The results for the employment specifications are presented in tables 3.1 and 3.2. Table 3.1 presents estimates for All and Large businesses, and table 3.2 presents estimates for the Small and Smaller size classes.

In table 3.1, the $\bar{R}^{2}$ 's are in the 75\% to 87\% range indicating good fit for the specifications. The estimates of the first-order autocorrelation coefficient, $\rho$, are relatively low on average. The estimates show that uncertainty related to GDP, Inflation, S\&P500 and Fuel prices have a negative effect on the growth of employment for All businesses, but the timing (contemporaneous versus lagged) and size of the estimated coefficients vary. Turning to the Large businesses, only Inflation and Fuel price uncertainty dampen growth of employment, and the estimated coefficients are a bit smaller for the Large business group.

For the small business groups in table 3.2 , the $\bar{R}^{2}$ s are in the $62 \%$ to $78 \%$ range. As before, the estimates of the first-order autocorrelation coefficient, $\rho$, are generally low. The estimates show that aside from the mixed inferences from the Inflation and S\&P500 based 
measures, uncertainty related to the two survey-based measures, and GDP, Inflation and Fuel prices have a negative effect on growth of employment for the Small and Smaller businesses.

As the coefficient estimates for the uncertainty measure vary across the different samples, we discuss whether these estimated coefficients are statistically different. First, consider the survey-based GDP uncertainty measure $\sigma_{s p g g d p}^{2}$. For the purposes of our illustration, let us impute a value of zero for any coefficient that is statistically insignificant. Based on this, for the All business group (table 3.1 and col. S1) and the Large business group (table 3.1, col. S1) the coefficients of $\sigma_{\text {spfgdp }}^{2}$ are 0.0. For the Small business group (table 3.2, col. S1) it is -0.0039 and highly significant, with a p-value of 0.008. Similarly, for the forecasting-based measure $\sigma_{g d p}^{2}$, the corresponding values are -0.0002 (statistically significant), 0.0 and -0.0038 (statistically significant). In the above cases, there is a clear difference in the estimated effects between the Large and Small business samples. We formally examined the underlying regression statistics to test whether we can reject the null hypothesis of equality of coefficients between the Large and Small groups. The Chow-tests rejected the null. Later, in table 5 below, we also present a clear comparison of the difference in estimated effects between the Large and Small groups.

The estimates in tables 3.1 and 3.2 can be summarized as follows. Most of the uncertainty coefficients indicate that employment growth in Large businesses is not sensitive to uncertainty; only GDP and stock price uncertainty have negative and significant effects on Large businesses. In contrast, almost all the uncertainty coefficients are significant for the Small and Smaller business groups. Overall, uncertainty dampens the growth of employment and the effects appear to be concentrated in the Smaller ( $<20$ employees) and Small ( $<500$ employees) business groups. At broad brush, our findings are supportive of the results from the theoretical models we discussed in section 2 . The fact that the effects related to uncertainty are significant even after controlling for GDP growth and the lagged autoregressive dynamics of employment, makes our findings noteworthy.

\section{GDP and growth of employment}

The estimated specifications include real GDP growth, and model the dynamics of the included variables via lagged effects. Real GDP growth is a critical control variable in growth of employment specifications. With increasing GDP growth, business opportunities are expected to expand allowing for growth of jobs. The estimates in tables 3.1 and 3.2 indicate that GDP 
growth, as contemporaneous and/or lagged effect, has a significant and positive effect on the growth of employment regardless of firm size. Examining the effect on large and small businesses, we see that GDP growth has a larger positive effect on Large firms in a 51\% to 74\% range. For the Smaller group ( $<20$ employees), the effects range varies from $6 \%$ to $47 \%$.

\subsection{Assessing quantitative effects}

As the means and standard deviations of the dependent and explanatory variables vary widely (table 1), the coefficient estimates in tables 3.1 and 3.2 do not convey a clear sense of the 'quantitative' importance of the effects related to uncertainty and GDP. In tables 4.1 and 4.2 we present the quantitative effects for growth of employment: in these two tables we do not report the regression statistics and details about lagged coefficients (as they are the same as those in tables 3.1 and 3.2) and focus only on the uncertainty and GDP growth effects.

The values in tables 4.1 and 4.2 show the effect of a one-standard-deviation (henceforth, one-s.d.) increase in the relevant independent variable. That is, if a particular uncertainty measure increased by one-s.d., the reported numbers show the estimated increase in growth of employment. We do not report the standard errors in tables 4.1 and 4.2 as they are the same as in tables 3.1 and 3.2, respectively. We keep the asterisk * notation to indicate if the particular quantitative effects are statistically significant at least at the $10 \%$ level. Finally, in the column headers in tables 4.1 and 4.2 we note the mean values of growth of employment for each category/size group.

As an illustration to interpret the numbers, consider table 4.2 and the reported numbers for the Smaller (<20) group. The reported numbers for $\sigma_{\text {spfgdp }}^{2}$ (column S1) are -0.0039 and 0.0044. Since both are statistically significant, the total effect is the sum of the two: -0.0083 . This implies that a one-s.d. increase in $\sigma_{s p f g d p}^{2}$ results in the growth of employment decreasing by 0.0083. This decline is to be compared to the mean growth of employment of 0.0053 for the Smaller $(<20)$ size group. The uncertainty-generated decline represents a relatively large quantitative effect for this group and specific measure of uncertainty.

To facilitate easy interpretation of the numbers, next we summarize all of the effects from tables 4.1 and 4.2, in table 5. In our above illustration, the total effect was -0.0083 . This number appears in table 5, column 1 and row 4 (uncertainty measure $\sigma_{\text {spfgdp }}^{2}$ and size group Smaller $(<20))$. 
The numbers in table 5 are interpreted as the total quantitative effects. In displaying the numbers in table 5 we only report those effects that are statistically significant. Since we are considering significance at least at the $10 \%$ level, this is a fairly safe-harbor threshold. If an estimate was not significant at least at the $10 \%$ level, for our illustrative purposes we assign a value of 0.0 .

Before examining the numbers in table 5, a final detail is that the column labeled $\overline{\sigma^{2}}$ reports the mean value of all the numbers in that particular row. This is then interpreted as the average estimated quantitative effect of uncertainty (across the various measures) on growth of employment for that particular sample (size class). The column labeled $\overline{G D P}$ is interpreted similarly; the average estimated quantitative effect of GDP growth on growth of employment for that particular sample (by size class). With these details in place, we are now in a position to comment on the total estimated quantitative effects for uncertainty and GDP growth.

From table 4, we see that the difference in effects between the Large (>500 employees) and Small (<500 employees) size groups is dramatic. The Small group effect is about 4.5 times larger than the Large group. While there are some variations across the specific measures of uncertainty, the effects of uncertainty on growth of employment, for all practical purposes, are felt largely by the relatively smaller businesses. The total quantitative effect for the Smaller $(<20)$ group is somewhat smaller than the Small $(<500)$ size group. This implies that the effects of uncertainty on some of the intermediate size classes is likely to be larger.

When comparing the relative quantitative effects of uncertainty $\left(\overline{\sigma^{2}}\right)$ to GDP growth $(\overline{G D P})$, we find that the quantitative effects of GDP growth are consistently larger.

\subsection{Comments on robustness of results}

Our analysis has several built-in checks of robustness. First, our key variable, the uncertainty measures, are constructed using two very different conceptual approaches: (a) A survey of professional forecasters based data. As noted in section 4, these surveys are conducted by the Federal Reserve Bank of Philadelphia and widely used in Economic and Business analysis and forecasting. The constructed measure of uncertainty is free of any econometric estimation induced problems; and 
(b) A forecasting-regression generated measure. This is based on a common procedure where forecasting specifications are estimated to pin down the regression parameters, and the forecast errors are used to measure uncertainty.

Second, we consider uncertainty about several alternative variables indicating the overall economy-wide conditions. These are GDP, industrial production, S\&P500, inflation and fuel prices. As we note in our summary of the literature, these variables have been used in the literature before.

In combination, these two aspects offer a measure of reassurance that our results related to uncertainty are not being driven by a single measure, procedure or variable.

In addition to the above, we conducted the following checks of robustness. Due to the rather space-consuming nature of the tables (as is evident from the set of tables 3-5), we do not report these in the paper. First, we estimated our forecasting specification (1) using longer autoregressive lag lengths, and generating the uncertainty measures. Second, we used augmented forecasting specifications where apart from using autoregressive lags of $\mathrm{Z}$ - as in specification (1) - we also included the growth of oil prices and a monetary policy variable, the Federal Funds Rate. The impact of oil prices and monetary policy actions on economy-wide variables such as GDP growth, inflation, stock price indices, among others, have been extensively examined and are standard in the macroeconomic literature. These controls are important because if agents and firms are using these variables to forecast movements in key economy-wide variables, ignoring them would produce potentially biased estimates of our uncertainty measures. Third, as opposed to the forecasting-based measures of uncertainty, we used the unconditional variance of GDP growth and the other variables to measure uncertainty. These are simply the variance of GDP growth and the other variables over alternative shorter time periods, using data over three, five and seven years. Across these alternative checks, our broader set of results and inferences related to the impact of uncertainty on growth of employment remain intact.

\section{Discussion of results and implications}

Our paper provides the first set of results in the literature on the differential effects of uncertainty on employment growth, and how this effect varies across firm size classes. Our findings on the differential effects of uncertainty on the employment dynamics of the smaller versus larger businesses are quite robust across alternative procedures for constructing the 
measures of uncertainty (survey of professional forecasters versus forecasting regression based methods), and alternative variables to measure uncertainty about (GDP, industrial production, inflation, S\&P500 and fuel prices). Our results related to uncertainty are robust to controlling for GDP growth and the lagged dynamics of the included variables.

The literature notes a rough equivalence between small businesses and entrepreneurship. ${ }^{15}$ Given the role of entrepreneurship in generating new firms, technologies and employment, our results on the effects of uncertainty on small businesses, therefore, also sheds light on the potentially adverse effects on entrepreneurial ventures.

The spirit of our results are not in isolation. Earlier studies on uncertainty, related to estimating the effects on investment spending, and using very different datasets and estimation procedures, have found similar results related to firm size: for example, Bianco et al. (2012), Ghosal and Loungani (1996, 2000), Ghosal (1991), Koetse and Vlist (2006) and Lensink et al. (2005). This is reassuring as it points to our results not being an artifact of our specific dataset, methods of estimation, or construction of uncertainty variables.

We used the insights from the theories related to real-options, information-asymmetry generated financing-constraints, and risk-preferences to obtain our predictions. As we noted in section 2, the real-options and risk-preference based theories do not offer clear predictions on why small and large firms may differ in their responses to uncertainty. ${ }^{16}$ The asymmetricinformation related financing-constraints theory on the other hand offered clear predictions, with smaller firms being the ones most likely to be adversely affected by uncertainty due to their greater likelihood of being financing constrained. ${ }^{17}$

A limitation of our study is the use of the U.S. Small Business Administration data which are aggregate. First, this makes it difficult to clearly disentangle which of the underlying theories may be playing the more dominant role. It is likely that both the real-options and financing-

\footnotetext{
${ }^{15}$ There is a significant literature which notes the similarities and differences between small business and entrepreneurship in dimensions related to growth and innovation. See, for example, ACCA (2010), Carland et al. (1984), di Giovanni et al. (2010) and Katz and Green (2010).

${ }^{16}$ Studies on industry dynamics and firm-churning data show that most business churning occurs at the smaller firm end: for example, Audretsch (1995), Sutton (1997) and Caves (1998). To this extent, purely as an accounting matter, one can argue that if we observe effects, it will more likely be in the smaller business category. But this is not a direct theoretical prediction.

${ }^{17}$ The literature has noted important differences between smaller and larger businesses, and point to smaller firms being relatively credit-constrained. E.g., Audretsch and Elston (1997), Fazzari, Hubbard and Petersen (1988), Gertler and Gilchrist (1994), Evans and Jovanovic (1989), Lensink, Bo and Sterken (2001), Ghosal and Loungani (2000), Himmelberg and Petersen (1994) and Winker (1999).
} 
constraints channels are important in determining the outcomes, with somewhat greater support for the financing-constraints channel due to the more direct predictions. Second, we cannot identify firms which change size class. For example, it might happen that there are small firms according to our definition who grow so that they are recorded as large firms in a future period. This implies that the employment growth may not be attributed to the correct firm size class, and the estimated coefficients may not precisely reflect the effect of uncertainty on employment growth. A fruitful extension of our study would be to address these issues using firm level data.

To the question as to why governments might pay special attention to small businesses, there are several responses. First, we noted that a large fraction of employment and businesses fall into the smaller categories. Second, a number of emerging structural factors - such as those related to globalization and banking sector consolidation - are likely to favor large businesses relative to the smaller ones. These considerations alone provide important economic policy justification.

If it is true that our results on the effects of uncertainty on employment dynamics in important part are being driven by the financing-constraints channel, then potential policy implications emerge. They are primarily in the form of initiatives and instruments designed to partly alleviate financing-constraints faced by smaller businesses. As with many governments worldwide, the U.S. recently implemented policies and programs to help small businesses bridge the capital and market gap and encouraged public-private partnerships to support small business and entrepreneurship by, for example: (a) supporting more than \$53 billion in SBA loan guarantees to more than 113,000 small businesses; (b) awarding more than \$221 billion in Federal contracts to small businesses (FY 2009 through April 30, 2011); and (c) awarding more than $\$ 4.5$ billion in research funding through the Small Business Innovation and Research Program during FY 2009 and FY 2010. ${ }^{18}$

Such initiatives, along with appropriate lending policies, can help ease some of the financing-constraints faced by smaller businesses in times of economic and financial distress. ${ }^{19}$ By doing so, and in the context of this paper, such policies may also help alleviate some of the negative impact of uncertainty on smaller businesses.

\footnotetext{
${ }^{18}$ The National Economic Council (2011) and Sheets and Sockin (2012) provide extensive discussion on the importance of small businesses and policy.

${ }^{19}$ The papers by Audretsch and Elston $(1997,2002)$, for example, provide important insights in this dimension from German policy initiatives.
} 
In terms of extensions of this line of research, it would be fruitful to conduct more detailed analysis using firm or industry level data. Firm or industry level data may allow us to better test the predictions from these models, and help us disentangle the likely effects of the information-asymmetry versus real-options channels. In addition, use of such data could allow us to examine the role played by structural characteristics of industries, such as R\&D and innovation intensity and other characteristics, in determining the effects of uncertainty. ${ }^{20}$

\footnotetext{
${ }^{20}$ There is strong evidence that financing constraints are tighter for more innovative and R\&D-intensive firms (e.g., Himmelberg and Petersen, 1994; Guiso, 1998; and Carpenter and Petersen, 2002). With firm or industry data one could use R\&D intensity or high-tech industries as a moderator of the uncertainty-employment relationship (in addition to firm size which we consider). We thank an anonymous referee for pointing this out.
} 


\section{Appendix A: Selected empirical findings on the impact of uncertainty}

The papers included below are not meant to be a comprehensive review of the studies in this area, but to display the range of variables used to measure uncertainty (GDP, inflation, prices, energy prices, stock prices, among others), the specific statistical constructs to capture uncertainty (unconditional variance, conditional variance derived from regression estimates, survey measures), the level of aggregation of the studies (firm, industry, and macroeconomic), and the estimated quantitative and qualitative effects.

\begin{tabular}{|c|c|c|c|}
\hline Paper & $\begin{array}{l}\text { Data } \\
\text { Estimation method }\end{array}$ & $\begin{array}{l}\text { State variables } \\
\text { Uncertainty measure }\end{array}$ & Estimation results \\
\hline $\begin{array}{l}\text { Lensink, Robert, Paul van Steen and } \\
\text { Elmer Sterken. “Uncertainty and } \\
\text { Growth of the Firm,” Small Business } \\
\text { Economics, 2005, 381-391. }\end{array}$ & $\begin{array}{l}\text { Survey of 1,097 Dutch firms in } \\
1999 . \\
\text { Logit model. }\end{array}$ & $\begin{array}{l}\text { Sales. Return on } \\
\text { Investment. } \\
\text { Conditional } \\
\text { variance/mean. }\end{array}$ & $\begin{array}{l}\text { Uncertainty has a negative impact on } \\
\text { the size of investment, no matter what } \\
\text { the type of investment is used. Smaller } \\
\text { firms have a lower probability to } \\
\text { invest if uncertainty increases. }\end{array}$ \\
\hline $\begin{array}{l}\text { Koetse, Mark J., Arno J. van der } \\
\text { Vlist and Henri L.F. de Groot. “The } \\
\text { Impact of Perceived Expectations } \\
\text { and Uncertainty on Firm } \\
\text { Investment,” Small Business } \\
\text { Economics, 2006, 365-376. }\end{array}$ & $\begin{array}{l}\text { Survey of } 135 \text { plant locations } \\
\text { in Netherlands in } 1998 . \\
\text { Tobit model. }\end{array}$ & $\begin{array}{l}\text { Wages. Energy prices. } \\
\text { Output prices. } \\
\text { Survey based. }\end{array}$ & $\begin{array}{l}\text { Uncertainty has a larger influence on } \\
\text { decision making in small firms than in } \\
\text { large firms specifically for investment } \\
\text { in energy-saving technologies. }\end{array}$ \\
\hline $\begin{array}{l}\text { Bo, Hong, and Elmer Sterken. } \\
\text { "Volatility of the interest rate, debt } \\
\text { and firm investment: Dutch } \\
\text { evidence," Journal of Corporate } \\
\text { Finance, 2002, 179-193. }\end{array}$ & $\begin{array}{l}\text { Data for } 41 \text { Dutch listed firms } \\
\text { from } 1984 \text { to } 1995 . \\
\text { Panel Data, , Fixed effect } \\
\text { estimation. }\end{array}$ & $\begin{array}{l}\text { Interest rate. } \\
\text { Conditional variance. } \\
\text { ARCH model. }\end{array}$ & $\begin{array}{l}\text { Cross-effect of the interest rate } \\
\text { volatility and debt on investment is } \\
\text { positive. This effect is more important } \\
\text { for highly indebted firms than for less- } \\
\text { indebted firms. }\end{array}$ \\
\hline $\begin{array}{l}\text { Driver, Ciaran, and Brendan Whelan. } \\
\text { "The Effect of Business Risk on } \\
\text { Manufacturing Investment,” Journal } \\
\text { of Economic Behavior and } \\
\text { Organization, 2001, 403-412. }\end{array}$ & $\begin{array}{l}\text { Disaggregated survey data of } \\
\text { Ireland in } 1995 . \\
\text { Comparing the percentage of } \\
\text { different respondents in the } \\
\text { survey questions. }\end{array}$ & $\begin{array}{l}\text { Future demand and } \\
\text { future price } \\
\text { Future unit input cost } \\
\text { Capacity } \\
\text { Delay risk } \\
\text { Subjective descriptions }\end{array}$ & $\begin{array}{l}\text { No strong effect of risk due to } \\
\text { convexities. Risk did affect the timing } \\
\text { of investment for between a quarter } \\
\text { and a third of the sample. The greatest } \\
\text { caution in respect of timing was in the } \\
\text { Hi-tech sector which was also the } \\
\text { sector with the greatest damage from } \\
\text { delay. }\end{array}$ \\
\hline $\begin{array}{l}\text { Oriani, Raffaele, and Maurizio } \\
\text { Sobrero. “Uncertainty and the } \\
\text { Market Valuation of R\&D within a } \\
\text { Real Options Logic," Strategic } \\
\text { Management Journal, 2008, 343- } \\
\text { 361. }\end{array}$ & $\begin{array}{l}\text { Data for } 290 \text { manufacturing } \\
\text { firms in UK from } 1989 \text { to } \\
1998 . \\
\text { Panel Data, Hedonic model }\end{array}$ & $\begin{array}{l}\text { Industry output. } \\
\text { Patents. } \\
\text { Absolute percentage } \\
\text { difference. Inverse of } \\
\text { the median age. } \\
\end{array}$ & $\begin{array}{l}\text { They find a U-shaped relationship } \\
\text { between market uncertainty and value } \\
\text { of investment. Also, they find an } \\
\text { inverted U-shaped relationship } \\
\text { between technological uncertainty and } \\
\text { the value of R\&D capital. }\end{array}$ \\
\hline $\begin{array}{l}\text { Bianco, Magda, Maria Elena } \\
\text { Bontempi, Roberto Golinelli and } \\
\text { Giuseppe Parigi. “Family Firms' } \\
\text { Investments, Uncertainty and } \\
\text { Opacity,” Small Business } \\
\text { Economics, 2012, 1-24. }\end{array}$ & $\begin{array}{l}\text { Data for 2,959 Italian private } \\
\text { companies from } 1996 \text { to } 2007 . \\
\text { Panel data, GMM }\end{array}$ & $\begin{array}{l}\text { Sales. } \\
\text { Coefficient of } \\
\text { variation. }\end{array}$ & $\begin{array}{l}\text { Family firms' investments are } \\
\text { significantly more sensitive to } \\
\text { uncertainty than nonfamily firms and } \\
\text { that is due to the greater opacity of } \\
\text { family firms and higher risk aversion, } \\
\text { rather than to the degree of sunk fixed } \\
\text { capital. }\end{array}$ \\
\hline $\begin{array}{l}\text { Bloom, Nick, Stephen Bond and } \\
\text { John Van Reenen. “Uncertainty and } \\
\text { Investment Dynamics,” Review of } \\
\text { Economic Studies, 2007, 391-415. }\end{array}$ & $\begin{array}{l}\text { Data for } 672 \text { UK } \\
\text { manufacturing firms from } 1972 \\
\text { to } 1991 . \\
\text { Panel data, GMM } \\
\end{array}$ & $\begin{array}{l}\text { Stock returns. } \\
\text { Std. deviation of daily } \\
\text { stock returns. }\end{array}$ & $\begin{array}{l}\text { Effects of uncertainty are large. } \\
\text { Uncertainty distribution halves the first } \\
\text { year investment response to demand } \\
\text { shocks. }\end{array}$ \\
\hline $\begin{array}{l}\text { Caglayan, Mustafa, Sara Maioli and } \\
\text { Simona Mateut. "Inventories, sales } \\
\text { uncertainty, and financial strength," } \\
\text { Journal of Banking \& Finance, } \\
\text { 2012, 2512-2521. }\end{array}$ & $\begin{array}{l}\text { Data on balance sheet } \\
\text { information for manufacturing } \\
\text { firms in European countries } \\
\text { including Belgium, Finland, } \\
\text { France, Italy and Spain from } \\
1999 \text { to } 2007 . \\
\text { Dynamic panel data approach, } \\
\text { GMM }\end{array}$ & $\begin{array}{l}\text { Sales } \\
\text { Standard deviation of } \\
\text { residuals. }\end{array}$ & $\begin{array}{l}\text { First, one standard deviation change in } \\
\text { sales uncertainty leads to four percent } \\
\text { change in inventory stock. } \\
\text { Second, sales uncertainty has an } \\
\text { indirect on inventories through its } \\
\text { effects on firms' net trade credit and } \\
\text { liquidity. Impact of uncertainty on } \\
\text { inventories is positive and significant } \\
\text { when the underlying financial strength } \\
\text { is low; however, after the financial }\end{array}$ \\
\hline
\end{tabular}




\begin{tabular}{|c|c|c|c|}
\hline & & & $\begin{array}{l}\text { strength exceeds a certain threshold, } \\
\text { the effect becomes insignificant. }\end{array}$ \\
\hline $\begin{array}{l}\text { Ghosal, Vivek, and Prakash } \\
\text { Loungani. “Product Market } \\
\text { Competition and the Impact of Price } \\
\text { Uncertainty on Investment: Some } \\
\text { Evidence From US Manufacturing } \\
\text { Industries,” Journal of Industrial } \\
\text { Economics, 1996, 217-228. }\end{array}$ & $\begin{array}{l}\text { Data for } 254 \text { US 4-digit SIC } \\
\text { manufacturing industries from } \\
1958 \text { to } 1989 . \\
\text { Panel data, fixed effect - IVE. }\end{array}$ & $\begin{array}{l}\text { Product price. } \\
\text { Rolling regression } \\
\text { based conditional std. } \\
\text { deviation. }\end{array}$ & $\begin{array}{l}\text { A negative relationship between } \\
\text { investment and price uncertainty only } \\
\text { exists in competitive industries. One } \\
\text { percentage increases in price } \\
\text { uncertainty is estimated to cause the } \\
\text { ratio of gross industry investment }(\mathrm{I} / \mathrm{K}) \\
\text { decrease by } 0.358 \text { for most } \\
\text { competitive industries. }\end{array}$ \\
\hline $\begin{array}{l}\text { Fuss, Catherine, and Philip } \\
\text { Vermeulen. "Firms' Investment } \\
\text { Decisions in Response to Demand } \\
\text { and Price Uncertainty,” Applied } \\
\text { Economics, 2008, 2337-2351. }\end{array}$ & $\begin{array}{l}\text { Survey of } 279 \text { firms from } \\
1987-2000 \text {, and another survey } \\
\text { of } 319 \text { firms from 1987-1999. } \\
\text { Panel data, GMM. }\end{array}$ & $\begin{array}{l}\text { Expectations of future } \\
\text { demand and prices. } \\
\text { Theil index. }\end{array}$ & $\begin{array}{l}\text { Demand uncertainty at the time of } \\
\text { planning depresses planned and } \\
\text { realized investment. One standard } \\
\text { deviation increases in demand } \\
\text { uncertainty is estimated to reduce 6\% } \\
\text { of the average investment ratio. }\end{array}$ \\
\hline $\begin{array}{l}\text { Ghosal, Vivek, and Prakash } \\
\text { Loungani. “The Differential Impact } \\
\text { of Uncertainty on Investment in } \\
\text { Small and Large Businesses,” } \\
\text { Review of Economics and Statistics, } \\
\text { 2000, 338-343. }\end{array}$ & $\begin{array}{l}\text { Data for } 330 \text { US SIC 4-digit } \\
\text { manufacturing industries from } \\
1958 \text { to } 1991 . \\
\text { Panel data, IVE. }\end{array}$ & $\begin{array}{l}\text { Profits. } \\
\text { Rolling regression } \\
\text { based conditional std. } \\
\text { deviation. }\end{array}$ & $\begin{array}{l}\text { Investment-uncertainty relationship is } \\
\text { negative and this negative impact is } \\
\text { greater in industries dominated by } \\
\text { small firms. }\end{array}$ \\
\hline $\begin{array}{l}\text { Gilchrist, Simon Jae W. Sim, Egon } \\
\text { Zakrajšek Uncertainty, Financial } \\
\text { Frictions, and Investment Dynamics } \\
\text { NBER Working Paper No. 20038, } \\
\text { 2014. }\end{array}$ & $\begin{array}{l}\text { Simulated data for 10,000 firms } \\
\text { from 1962:Q1 to 2012:Q3. } \\
\text { Structural vector autoregression }\end{array}$ & $\begin{array}{l}\text { Daily stock returns } \\
\text { Standard deviation of } \\
\text { daily idiosyncratic } \\
\text { returns }\end{array}$ & $\begin{array}{l}\text { Uncertainty affects financial } \\
\text { conditions of firms by significantly } \\
\text { altering the level of credit spread in the } \\
\text { economy. }\end{array}$ \\
\hline $\begin{array}{l}\text { Huizinga, John. "Inflation } \\
\text { Uncertainty, Relative Price } \\
\text { Uncertainty, and Investment in U.S. } \\
\text { Manufacturing,” Journal of Money, } \\
\text { Credit and Banking, 1993, 521-549. }\end{array}$ & $\begin{array}{l}\text { Data for } 450 \text { U.S. SIC 4-digit } \\
\text { manufacturing industries from } \\
1954 \text { to } 1989 . \\
\text { Cross-sectional data. }\end{array}$ & $\begin{array}{l}\text { Real wage. Output } \\
\text { price. Real materials } \\
\text { price. } \\
\text { Conditional std. } \\
\text { deviation. } \\
\text { Bivariate ARCH } \\
\text { model. } \\
\end{array}$ & $\begin{array}{l}\text { Increased uncertainty about real wages } \\
\text { portends an immediate and large drop } \\
\text { in capital expenditures, while } \\
\text { increased uncertainty about real output } \\
\text { price does not. }\end{array}$ \\
\hline $\begin{array}{l}\text { Stein, Luke C.D., and Elizabeth C. } \\
\text { Stone. "The Effect of Uncertainty on } \\
\text { Investment: Evidence from } \\
\text { Options,” Stanford University } \\
\text { Working Paper, } 2010 .\end{array}$ & $\begin{array}{l}\text { Data for 2,230 US } \\
\text { manufacturing firms from } 1996 \\
\text { to } 2009 . \\
\text { Panel data, 2SLS. }\end{array}$ & $\begin{array}{l}\text { Stock price. } \\
\text { Expected volatility. }\end{array}$ & $\begin{array}{l}\text { They find a negative and statistically } \\
\text { significant relationship between } \\
\text { uncertainty and investment. The } \\
\text { coefficients are larger after addressing } \\
\text { the endogeneity of the uncertainty } \\
\text { measure. }\end{array}$ \\
\hline $\begin{array}{l}\text { Folta, Timothy, and Jonathan P. } \\
\text { O’Brien. "Entry in the Presence of } \\
\text { Dueling Options," Strategic } \\
\text { Management Journal, 2004, 121- } \\
\text { 138. }\end{array}$ & $\begin{array}{l}\text { Data for } 2,230 \text { US } \\
\text { manufacturing firms from } 1996 \\
\text { to } 2009 \text { and } 17,897 \text { firms from } \\
1980 \text { to } 1999 . \\
\text { Multivariate binomial logit } \\
\text { model }\end{array}$ & $\begin{array}{l}\text { Industry's contribution } \\
\text { to GDP. } \\
\text { Square root of } \\
\text { conditional variance. } \\
\text { GARCH model. }\end{array}$ & $\begin{array}{l}\text { They find the effect of uncertainty on } \\
\text { entry is non-monotonic and U-shaped. } \\
\text { And the turning points are influenced } \\
\text { by factors which should influence } \\
\text { options to grow and defer. Uncertainty } \\
\text { has a potent effect on entry even after } \\
\text { controlling for firm resource profiles, } \\
\text { including the relatedness to the target } \\
\text { industry. }\end{array}$ \\
\hline $\begin{array}{l}\text { Baker, Scott, Nick Bloom and } \\
\text { Steven J. Davis. “Has Economic } \\
\text { Policy Uncertainty Hampered the } \\
\text { Recovery?” Chicago Booth Paper, } \\
\text { No. 12-06, 2012. }\end{array}$ & $\begin{array}{l}\text { Index of economic policy } \\
\text { uncertainty, news-based proxy, } \\
\text { government purchases data, } \\
\text { disagreement about future } \\
\text { indexes from } 1985 \text { to } 2011 . \\
\text { And tax code expiration data is } \\
\text { from } 1991 \text { to } 2011 . \\
\text { VAR model }\end{array}$ & $\begin{array}{l}\text { Merge economic policy } \\
\text { uncertainty, news-based } \\
\text { proxy, government } \\
\text { purchases data and } \\
\text { disagreement about } \\
\text { future indexes into a } \\
\text { new proxy. } \\
\text { Aggregating the above } \\
\text { Components to Obtain } \\
\text { an Index of Economic } \\
\text { Policy Uncertainty }\end{array}$ & $\begin{array}{l}\text { High levels of policy uncertainty in } \\
2010 \text { and } 2011 \text { mainly reflect concerns } \\
\text { about tax and monetary policy. Policy- } \\
\text { related concerns account for a large } \\
\text { share of overall economic uncertainty. } \\
\text { A rise in policy uncertainty is } \\
\text { associated with substantially lower } \\
\text { levels of output and employment } \\
\text { compared with that of actual changes } \\
\text { since 2006. }\end{array}$ \\
\hline $\begin{array}{l}\text { Driver, Ciaran, Paul Temple and } \\
\text { Giovanni Urga. "Profitability, } \\
\text { capacity, and uncertainty: a model of } \\
\text { UK manufacturing investment," } \\
\text { Oxford Economic Papers, 2005, } \\
120-141 .\end{array}$ & $\begin{array}{l}\text { Aggregate data of UK } \\
\text { manufacturing on two capital } \\
\text { assets (machinery and building) } \\
\text { from } 1972 \text { to } 1999 . \\
\\
\text { Linear-quadratic model }\end{array}$ & $\begin{array}{l}\text { Output growth. } \\
\text { Time-series conditional } \\
\text { volatility. GARCH } \\
\text { model }\end{array}$ & $\begin{array}{l}\text { The GARCH model shows uncertainty } \\
\text { variable for the full sample are } \\
\text { estimated to be negatively significant } \\
\text { at the } 5 \% \text { level for machinery, and } \\
\text { negative but not significant for } \\
\text { building. }\end{array}$ \\
\hline
\end{tabular}




\begin{tabular}{|c|c|c|c|}
\hline $\begin{array}{l}\text { Greasley, David, and Jakob B. } \\
\text { Madsen. “Investment and } \\
\text { Uncertainty: Precipitating the Great } \\
\text { Depression in the United States,” } \\
\text { Economica, 2006, 393-412. }\end{array}$ & $\begin{array}{l}\text { Data of investment information } \\
\text { in US from } 1920 \text { to } 1938 .\end{array}$ & $\begin{array}{l}\text { Squared monthly } \\
\text { proportional change. }\end{array}$ & $\begin{array}{l}\text { Effects of uncertainty of the expected } \\
\text { marginal profitability of capital can } \\
\text { explain around } 80 \% \text { of the actual fall } \\
\text { in the business fixed investment ratio } \\
\text { in } 1930 \text {. Thus, the investment slump } \\
\text { largely led the declines in income. }\end{array}$ \\
\hline $\begin{array}{l}\text { Kilian, Lutz. "Exogenous Oil Supply } \\
\text { Shocks: How Big Are They and How } \\
\text { Much Do They Matter for the U.S. } \\
\text { Economy?” Review of Economics } \\
\text { and Statistics. 2008, 216-240. }\end{array}$ & $\begin{array}{l}\text { Monthly production data for all } \\
\text { OPEC countries and for } \\
\text { aggregate non-OPEC oil } \\
\text { production since } 1973 . \\
\text { OLS }\end{array}$ & $\begin{array}{l}\text { Oil production. } \\
\text { Exogenous variation. }\end{array}$ & $\begin{array}{l}\text { Using new exogenous oil supply shock } \\
\text { measure, it finds statistically } \\
\text { significant evidence of a sharp drop in } \\
\text { real GDP growth and of a spike in CPI } \\
\text { inflation after an exogenous oil supply } \\
\text { shock. }\end{array}$ \\
\hline $\begin{array}{l}\text { Guo, Hui, and Kevin L. Kliesen. } \\
\text { “Oil Price Volatility and U.S. } \\
\text { Macroeconomic Activity,” Federal } \\
\text { Reserve Bank of St. Louis Review, } \\
\text { 2005, 669-83. }\end{array}$ & $\begin{array}{l}\text { Data of daily price of U.S. 1- } \\
\text { month futures and 12- month } \\
\text { futures contracts from } 1983 \text { to } \\
2004 . \\
\text { Forecasting regression }\end{array}$ & $\begin{array}{l}\text { Oil prices. } \\
\text { Realized variance } \\
\text { series. }\end{array}$ & $\begin{array}{l}\text { Oil price volatility has a negative and } \\
\text { significant effect on future GDP } \\
\text { growth over the period 1984-2004. } \\
\text { Moreover, the effect becomes more } \\
\text { significant after oil price changes are } \\
\text { also included in the regression to } \\
\text { control for the symmetric effect. }\end{array}$ \\
\hline $\begin{array}{l}\text { Elder, John. "Another Perspective on } \\
\text { the Effects of Inflation Uncertainty," } \\
\text { Journal of Money, Credit \& } \\
\text { Banking, 2004, 911-928. }\end{array}$ & $\begin{array}{l}\text { Data of U.S. output growth } \\
\text { rate, inflation, CPI, commodity } \\
\text { price from } 1966 \text { to } 2000 . \\
\text { Cross-section data, } \\
\text { VAR model }\end{array}$ & $\begin{array}{l}\text { Inflation } \\
\text { Conditional variance. } \\
\text { MGARCH-M VAR } \\
\text { model }\end{array}$ & $\begin{array}{l}\text { Uncertainty about inflation has } \\
\text { significantly reduced real economic } \\
\text { activity over the post- } 1982 \text { period. One } \\
\text { standard deviation increase in inflation } \\
\text { uncertainty tends to reduce real } \\
\text { economic activity by about } 22 \text { basis } \\
\text { points in the post- } 1982 \text { period. }\end{array}$ \\
\hline $\begin{array}{l}\text { Fountas, Stilianos, Menelaos } \\
\text { Karanasos and Jinki Kim. “Inflation } \\
\text { Uncertainty, Output Growth } \\
\text { Uncertainty and Macroeconomic } \\
\text { Performance,” Oxford Bulletin of } \\
\text { Economics and Statistics. 2006, 319- } \\
343 .\end{array}$ & $\begin{array}{l}\text { VAR model. Granger-causality } \\
\text { tests }\end{array}$ & $\begin{array}{l}\text { Bivariate GARCH } \\
\text { model. Conditional } \\
\text { variance }\end{array}$ & $\begin{array}{l}\text { First, inflation causes negative welfare } \\
\text { effect. Second, in some countries } \\
\text { (Canada and the UK) more inflation } \\
\text { uncertainty provokes Central Banks to } \\
\text { surprise the public by raising inflation } \\
\text { unexpectedly. Thirdly, More business } \\
\text { cycle variability increases output } \\
\text { growth. }\end{array}$ \\
\hline $\begin{array}{l}\text { Denis, Stephanie and Prakash } \\
\text { Kannan. “The Impact of Uncertainty } \\
\text { Shocks on the UK Economy,” IMF } \\
\text { Working Paper No. 13/66. 2013. }\end{array}$ & $\begin{array}{l}\text { Monthly data from June } 1984 \\
\text { to September } 2011 . \\
\text { VAR model }\end{array}$ & $\begin{array}{l}\text { Stock market volatility } \\
\text { GDP forecast } \\
\text { Weighted average } \\
\text { measure of current and } \\
\text { next year forecasts. } \\
\end{array}$ & $\begin{array}{l}\text { First, uncertainty has a substantial } \\
\text { effect on UK industrial production, } \\
\text { unemployment and GDP. }\end{array}$ \\
\hline $\begin{array}{l}\text { Ghosal, Vivek. "Demand } \\
\text { Uncertainty and Capital-Labor } \\
\text { Ration: Evidence from U.S. } \\
\text { manufacturing Sector,” The Review } \\
\text { of Economics and Statistics, 1991, } \\
\text { 157-161. }\end{array}$ & $\begin{array}{l}\text { Date for } 125 \text { U.S. } \\
\text { manufacturing industries from } \\
1968 \text { to } 1977 . \\
\text { OLS }\end{array}$ & $\begin{array}{l}\text { Fluctuations of } \\
\text { shipments } \\
\text { Standard deviation }\end{array}$ & $\begin{array}{l}\text { There is a significant negative } \\
\text { relationship between demand } \\
\text { uncertainty and the capital-labor ratio, } \\
\text { and that an increase in firm size } \\
\text { counteracts this negative influence. }\end{array}$ \\
\hline $\begin{array}{l}\text { Ghosal, Vivek. "Does uncertainty } \\
\text { influence the number of firms in an } \\
\text { industry?” Economics Letters, 1996, } \\
\text { 229-236. }\end{array}$ & $\begin{array}{l}\text { Date for } 196 \text { U.S. industries } \\
\text { from 1973-1986. } \\
\text { IV Estimation } \\
\end{array}$ & $\begin{array}{l}\text { Industry-specific price } \\
\text { Standard deviation of } \\
\text { residuals }\end{array}$ & $\begin{array}{l}\text { Price uncertainty has a statistically } \\
\text { significant and quantitatively large } \\
\text { negative impact on the number of } \\
\text { firms in an industry. }\end{array}$ \\
\hline $\begin{array}{l}\text { Li, Yong. “Duration analysis of } \\
\text { venture capital staging: A real } \\
\text { options perspective,” Journal of } \\
\text { Business Venturing, 2008, 497-512. }\end{array}$ & $\begin{array}{l}\text { 46,976 portfolio company- } \\
\text { round pairs in U.S. for } 1975- \\
2005 \text {, involving } 3737 \text { venture } \\
\text { capital firms and } 15,786 \\
\text { portfolio companies. } \\
\text { Weibull regression model } \\
\end{array}$ & $\begin{array}{l}\text { Market price volatility; } \\
\text { The stage of } \\
\text { development. } \\
\text { Conditional variance } \\
\text { for market uncertainty } \\
\text { GARCH model }\end{array}$ & $\begin{array}{l}\text { Market uncertainty encourages venture } \\
\text { capital firms to delay investing at each } \\
\text { round of financing, whereas } \\
\text { competition, project-specific } \\
\text { uncertainty and agency concerns } \\
\text { prompt venture capital firms to invest } \\
\text { sooner. }\end{array}$ \\
\hline $\begin{array}{l}\text { Podoynitsyna, Ksenia, Michael } \\
\text { Song, Hans van der Bij and Mathieu } \\
\text { Weggeman. “Improving new } \\
\text { technology venture performance } \\
\text { under direct and indirect network } \\
\text { externality conditions,” Journal of } \\
\text { Business Venturing, } 2013 \text { 195-210. }\end{array}$ & $\begin{array}{l}\text { A sample of } 385 \text { NTVs drawn } \\
\text { from the VentureOne } 2001 \\
\text { database and the 1995-2000 } \\
\text { Inc. } 500 \text { list. } \\
\text { OLS multiple regression }\end{array}$ & $\begin{array}{l}\text { Five main uncertainty } \\
\text { management strategies } \\
\text { Use scales to measure } \\
\text { each of the five } \\
\text { strategies. }\end{array}$ & $\begin{array}{l}\text { They show that real option reasoning } \\
\text { does not always perform better under } \\
\text { conditions of higher uncertainty, such } \\
\text { as uncertainty due to direct network } \\
\text { externalities. }\end{array}$ \\
\hline $\begin{array}{l}\mathrm{Li} \text {, Yong, Joseph T. Mahoney “When } \\
\text { are venture capital projects } \\
\text { initiated?” Journal of Business } \\
\text { Venturing, 2011, 239-254. }\end{array}$ & $\begin{array}{l}\text { Date of venture capital } \\
\text { investment of 22,164 ventures } \\
\text { made between } 1980 \text { and } 2007 \\
\text { in the U.S. }\end{array}$ & $\begin{array}{l}\text { Volatility of market } \\
\text { returns. } \\
\text { The standard error of } \\
\text { the regression. }\end{array}$ & $\begin{array}{l}\text { Venture capitalists tend to defer new } \\
\text { investment projects in target industries } \\
\text { with substantial market volatility. This } \\
\text { delay effect is reduced if the target }\end{array}$ \\
\hline
\end{tabular}




\begin{tabular}{|c|c|c|c|}
\hline & $\begin{array}{l}\text { Accelerated-failure-time } \\
\text { models }\end{array}$ & & $\begin{array}{l}\text { industry experiences high sales growth } \\
\text { or if competition is intense. }\end{array}$ \\
\hline $\begin{array}{l}\text { Li, Dan. “Multilateral R\&D alliances } \\
\text { by new ventures," Journal of } \\
\text { Business Venturing, 2013, 241-260. }\end{array}$ & $\begin{array}{l}346 \text { new ventures in high- } \\
\text { technology industries from } \\
1990 \text { to } 2005 . \\
\text { Heckman two-stage } \\
\text { regressions. }\end{array}$ & $\begin{array}{l}\text { Mean monthly stock } \\
\text { price volatility. } \\
\text { Standard deviation. }\end{array}$ & $\begin{array}{l}\text { An inverted U-shaped relationship } \\
\text { between market uncertainty and a new } \\
\text { venture's likelihood of forming } \\
\text { multilateral R\&D alliances. }\end{array}$ \\
\hline $\begin{array}{l}\text { Freel, Mark S.. "Perceived } \\
\text { Environmental Uncertainty and } \\
\text { Innovation in Small Firms," Small } \\
\text { Business Economics, 2005, 49-64. }\end{array}$ & $\begin{array}{l}\text { Firm-level survey data of UK } \\
\text { SMEs in 1996, 1998, } 2000 . \\
\text { Discriminant functions }\end{array}$ & $\begin{array}{l}\text { Supply, finance, } \\
\text { competitors, trade } \\
\text { Asking the firms to } \\
\text { report their feeling of } \\
\text { uncertainty on a five- } \\
\text { point scale. }\end{array}$ & $\begin{array}{l}\text { Higher levels of innovation in } \\
\text { manufacturing firms are associated } \\
\text { with higher perceptions of supplier } \\
\text { uncertainty, whilst, higher levels of } \\
\text { innovation in service firms are } \\
\text { associated with higher perceptions of } \\
\text { human resource uncertainty. }\end{array}$ \\
\hline $\begin{array}{l}\text { Drakos, Konstantinos and Panagiotis } \\
\text { T. Konstantinou. "Investment } \\
\text { Decisions in Manufacturing: } \\
\text { Assessing the Effects of Real Oil } \\
\text { Prices and their Uncertainty,” } \\
\text { Journal of Applied Econometrics. } \\
\text { 2013, 151-165. }\end{array}$ & $\begin{array}{l}\text { Data of } 51881 \text { plant-year } \\
\text { observations for Greece for the } \\
\text { period } 1994 \text { to } 2005 . \\
\text { Unbalanced panel data. } \\
\text { Dynamic discrete choice } \\
\text { models. }\end{array}$ & $\begin{array}{l}\text { Real oil price. } \\
\text { Profits. } \\
\text { Daily stock returns } \\
\text { from the Industrials } \\
\text { Price Index. } \\
\text { GARCH model. }\end{array}$ & $\begin{array}{l}\text { Using he CRE estimators of } \\
\text { Wooldridge, they find that that an } \\
\text { increase in measure of real oil price } \\
\text { uncertainty by } 0.01 \text { reduces the } \\
\text { probability of investment action by } \\
0.46 \text { percent. } \\
\text { Smaller plants are influenced more } \\
\text { by rising real oil-price uncertainty. }\end{array}$ \\
\hline
\end{tabular}




\section{References}

Abdellaoui, Mohammed, Han Bleichrodt, Corina Paraschiv. "Loss Aversion under Prospect Theory: A Parameter-free Measurement,” Management Science, 2007, 1659 - 1674. (doi: 10.1287/mnsc.1070.0711)

Abel, Andrew. “Optimal Investment under Uncertainty,” American Economic Review 73, 1983, 228-233.

Abel, Andrew, Avinash Dixit, Janice Eberly and Robert Pindyck. "Options, the Value of Capital, and Investment,” Quarterly Journal of Economics 111, 1996, 753-777. (doi: 10.2307/2946671)

Abowd, John M. and Francis Kramarz. "The Costs of Hiring and Separations,” Labour Economics 10, 2003, 499-530. (doi: 10.1016/S0927-5371(03)00017-4)

Appelbaum, Elie, and Eliakim Katz. "Measures of Risk Aversion and Comparative Statics of Industry Equilibrium,” American Economic Review, 1986, 524-529.

Association of Chartered Certified Accountants (ACCA). "Small Business: A Global Agenda," ACCA Accountants for Business Report, 2010.

Audretsch, David. Innovation and Industry Evolution. Cambridge: MIT Press, 1995.

Audretsch, David, and Julie Elston. "Does Firm Size Matter? Evidence on the Impact of Liquidity Constraints on Firm Investment Behavior in Germany,” International Journal of Industrial Organization, 2002, 1-17. (doi: 10.1016/S0167-7187(00)00072-2)

Audretsch, David, and Julie Elston. "Financing the German Mittelstand,” Small Business Economics, 1997, 97-110. (doi: 10.1023/A:1007963621438)

Baker, Scott, Nicholas Bloom and Steven Davis. "Has Economic Policy Uncertainty Hampered the Recovery?” Chicago Booth Paper, No. 12-06, 2012. (doi: 10.2139/ssrn.2000734)

Baldwin, John, Guy Gellatly and Valérie Gaudreault. "Financing Innovation in New Small Firms: New Evidence From Canada,” Statistics Canada Analytical Studies Series, 2002. (doi: 10.2139/ssrn.316849)

Bianco, Magda, Maria Elena Bontempi, Roberto Golinelli and Giuseppe Parigi. "Family Firms' Investments, Uncertainty and Opacity,” Small Business Economics, 2013, 1035-1058. (doi: 10.1007/s11187-012-9414-3 )

Bloom, Nick, Stephen Bond and John van Reenen. "Uncertainty and Investment Dynamics," Review of Economic Studies, 2007, 391-415. (doi: 10.1111/j.1467-937X.2007.00426.x) 
Bo, Hong, and Elmer Sterken. "Volatility of the Interest Rate, Debt and Firm Investment: Dutch Evidence,” Journal of Corporate Finance, 2002, 179-193. (doi: 10.1016/S0929-1199(01)000311)

Bowman, Edward. “A Risk-Return Paradox for Strategic Management,” Sloan Management Review 21, 1980, 17-31.

Bowman, Edward. “Risk Seeking by Troubled Firms,” Sloan Management Review 23, 1982, 3342.

Box, G.E.P., and G.M. Jenkins. Time Series Analysis, Forecasting and Control. San Francisco: Holden Day, 1970.

Caballero, Ricardo J. and Eduardo M. R. A. Engel. "Microeconomic Adjustment Hazards and Aggregate Dynamics,” Quarterly Journal of Economics 108, 1993, 359-83. (doi:

$10.2307 / 2118335)$

Caballero, Ricardo J., Eduardo M. R. A. Engel, and John Haltiwanger. “Aggregate Employment Dynamics: Building from Microeconomic Evidence,” American Economic Review 87, 1997, 115-37. (doi: 10.3386/w5042)

Caglayan, Mustafa, Sara Maioli and Simona Mateut. "Inventories, sales uncertainty, and financial strength,” Journal of Banking \& Finance, 2012, 2512-2521. (doi:

10.1016/j.jbankfin.2012.05.006)

Carland, J.W., F. Hoy, W. R. Boulton, and J.A.C. Carland, "Differentiating Entrepreneurs from Small Business Owners: A Conceptualization,” Academy of Management Review, 1984, 358. (doi: 10.1007/978-3-540-48543-8_3)

Carpenter, Robert E., and Bruce C. Petersen. "Capital Market Imperfections, High-Tech Investment, and New Equity Financing,” Economic Journal 112, 2002, F54-F72. (doi: 10.1111/1468-0297.00683)

Caves, Richard. "Industrial Organization and New Findings on the Turnover and Mobility of Firms,” Journal of Economic Literature, 1998, 1947-1982.

Campbell, John, and John Cochrane. "By Force of Habit: A Consumption-Based Explanation of Aggregate Stock Market Behavior,” Journal of Political Economy 107, 1999, 205-251. (doi: 10.1086/250059)

Cooper, Russell, and Jonathan L. Willis. "The Cost of Labor Adjustment: Inferences from the Gap,” Review of Economic Dynamics 12, 2009, 632-647. (doi: /10.1016/j.red.2008.12.001)

Delli Gatti, Domenico, Mauro Gallegati, Gianfranco Giulioni and Antonio Palestrini. "Financial Fragility, Patterns of Firms' Entry and Exit and Aggregate Dynamics," Journal of Economic Behavior and Organization 51, 2003, 79-97. (doi: 10.1016/S0167-2681(02)00138-5) 
Denis, Stephanie and Prakash Kannan. "The Impact of Uncertainty Shocks on the UK Economy,” IMF Working Paper No. 13/66, 2013.

Dixit, Avinash. "Entry and Exit Decisions under Uncertainty,” Journal of Political Economy 97, 1989, 620-638.

Dixit, Avinash, and Robert Pindyck. “The Options Approach to Capital Investment,” Harvard Business Review (May), 1995.

Driver, Ciaran, Paul Temple and Giovanni Urga. "Profitability, Capacity, and Uncertainty: A Model of UK Manufacturing Investment,” Oxford Economic Papers, 2005, 120-141. (doi:

10.1093/oep/gpi001)

Driver, Ciaran, and Brendan Whelan. "The Effect of Business Risk on Manufacturing Investment,” Journal of Economic Behavior and Organization 44, 2001, 403-412. (doi: 10.1016/S0167-2681(00)00145-1)

Economist. “Uncertainty and unemployment,” 2013, The Economist.

Evans, David and Boyan Jovanovic. “An Estimated Model of Entrepreneurial Choice under Liquidity Constraints,” Journal of Political Economy, 1989, 808-827.

Fazzari, Steven, Glenn Hubbard and Bruce Petersen, "Financing Constraints and Corporate Investment.” Brookings Papers on Economic Activity, 1988, 141-195. (doi: 10.3386/w2387)

Federal Reserve Bank of Philadelphia. “Survey of Professional Forecasters.”

Fiegenbaum, Avi, and Howard Thomas. "Attitudes towards risk and the risk-return paradox: Prospect theory explanations,” Academy of Management Journal 31, 1988, 85-106. (doi: 10.2307/256499)

Folta, Timothy, and Jonathan O’Brien. "Entry in the Presence of Dueling Options," Strategic Management Journal, 2004, 121-138. (doi: 10.1002/smj.368)

Fountas, Stilianos, Menelaos Karanasos and Jinki Kim. "Inflation Uncertainty, Output Growth Uncertainty and Macroeconomic Performance," Oxford Bulletin of Economics and Statistics. 2006, 319-343. (doi: 10.1111/j.1468-0084.2006.00164.x)

Freel, Mark S. "Perceived Environmental Uncertainty and Innovation in Small Firms,” Small Business Economics, 2005, 49-64. (doi: 10.1007/s11187-005-4257-9)

Fuss, Catherine, and Philip Vermeulen. “Firms’ Investment Decisions in Response to Demand and Price Uncertainty,” Applied Economics, 2008, 2337-2351. (doi: 10.2139/ssrn.1691622) 
Gertler, Mark, and Simon Gilchrist. "Monetary Policy, Business Cycles, and the Behavior of Small Manufacturing Firms,” Quarterly Journal of Economics, 1994, 309-340. (doi:

$10.2307 / 2118465)$

Ghosal, Vivek. “The Effects of Uncertainty and Sunk Costs on Firms’ Decision-Making:

Evidence from Net Entry, Industry Structure and Investment Dynamics.” In The Economics of Imperfect Markets, Giorgio Calcagnini and Enrico Saltari (Eds.), Contributions to Economics, Springer: New York, 2009, Chapter 9, pages 167 - 182. (doi: 0.1007/978-3-7908-2131-4_9)

Ghosal, Vivek, and Prakash Loungani. "The Differential Impact of Uncertainty on Investment in Small and Large Businesses,” Review of Economics and Statistics, 2000, 338-343. (doi: 10.2139/ssrn.236097)

Ghosal, Vivek, and Prakash Loungani. "Product Market Competition and the Impact of Price Uncertainty on Investment: Some Evidence From US Manufacturing Industries,” Journal of Industrial Economics, 1996, 217-228. (doi: 10.2307/2950647)

Ghosal, Vivek. "Does Uncertainty Influence the Number of Firms in an Industry?” Economics Letters 50, 1996, 229 - 237. (10.1016/0165-1765(95)00747-4)

Ghosal, Vivek. “Input Choices under Price Uncertainty.” Economic Inquiry 33, 1995, 142-158. (doi: 10.1111/j.1465-7295)

Ghosal, Vivek. "Demand Uncertainty and the Capital-Labor Ratio: Evidence from the U.S. Manufacturing Sector,” Review of Economics and Statistics 73, 1991, 157 - 162. (doi: $10.2307 / 2109699)$

Gilchrist, Simon Jae W. Sim, Egon Zakrajšek. "Uncertainty, Financial Frictions, and Investment Dynamics,” NBER Working Paper No. 20038, 2014. (doi: 10.3386/w20038)

Gollier, Christian, and Richard Zeckhauser. “Aggregation of Heterogeneous Time Preferences,” Journal of Political Economy 113, 2005, 878-896. (doi: 10.1086/430853)

Greasley, David, and Jakob Madsen. "Investment and Uncertainty: Precipitating the Great Depression in the United States,” Economica, 2006, 393-412. (doi: 10.1111/j.14680335.2006.00505.x)

Greenwald, Bruce, and Joseph Stiglitz. "Information, Finance, and Markets: The Architecture of Allocative Mechanisms,” Industrial and Corporate Change 1, 1992, 37-63. (doi: 10.3386/w3652)

Greenwald, Bruce, and Joseph Stiglitz. “Asymmetric Information and the New Theory of the Firm: Financial Constraints and Risk Behavior,” American Economic Review 80, 1990(a), 160165. 
Greenwald, Bruce, and Joseph Stiglitz. "Macroeconomic Models with Equity and Credit Rationing,” in Hubbard, R. Glenn. ed., Asymmetric Information, Corporate Finance, and Investment. Chicago: University of Chicago Press, 1990(b), 15-42. (doi: 10.3386/w3533)

Greenwald, Bruce, Joseph Stiglitz and Andrew Weiss. "Informational Imperfections in the Capital Market and Macroeconomic Fluctuations,” American Economic Review 74, 1984, 194199.

Guiso, Luigi. "High-Tech Firms and Credit Rationing.” Journal of Economic Behavior and Organization 35, 1998, 39-59. (doi: 10.1016/S0167-2681(97)00101-7)

Guo, Hui, and Kevin Kliesen. “Oil Price Volatility and U.S. Macroeconomic Activity,” Federal Reserve Bank of St. Louis Review, 2005, 669-83. (doi: 10.3886/ICPSR01322.v1)

Hamermesh, Daniel S. “A General Model of Dynamic Labor Demand,” Review of Economics and Statistics 74, 1992, 733-37. (doi: 10.2307/2109390)

Hamermesh, Daniel S. and Gerard A. Pfann. “Adjustment Costs in Factor Demand,” Journal of Economic Literature 34, 1996, 1264-1292.

Hartman, Richard. "Factor Demand with Output Price Uncertainty,” American Economic Review, 1976, 675-681.

Hartman, Richard. “Adjustment costs, price and wage uncertainty, and investment,” Review of Economic Studies 40, 1973, 259-267. (doi: 10.2307/2296652)

Hartman, Richard. “The Effects of Price and Cost Uncertainty on Investment,” Journal of Economic Theory 5, 1972, 258-266. (doi: 10.1016/0022-0531(72)90105-6)

Hendry, David, Adrian Pagan and Denis Sargan. “Dynamic Specification,” in Zvi Griliches and Michael Intriligator (Eds.), Handbook of Econometrics, Amsterdam: North-Holland, 1983. (doi: 10.1016/S1573-4412(84)02010-9)

Himmelberg, Charles, and Bruce Petersen. "R \& D and Internal Finance: A Panel Study of Small Firms in High-Tech Industries,” Review of Economics and Statistics 76, 1994, 38-51. (doi:

10.2307/2109824)

Holt Charles, Franco Modigliani, John Muth and Herbert Simon. Planning Production, Inventories and Work Force, Englewood Cliffs: Prentice Hall, 1960.

Huizinga, John. “Inflation Uncertainty, Relative Price Uncertainty, and Investment in U.S. Manufacturing,” Journal of Money, Credit and Banking, 1993, 521-549. (doi: 10.2307/2077721)

Jorgenson, Dale. “Econometric Methods for Modeling Producer Behavior," in Zvi Griliches and Michael Intriligator (Eds.), Handbook of Econometrics, Amsterdam: North Holland, 1986. (doi: 10.1016/S1573-4412(86)03011-8) 
Kahneman, Daniel, and Amos Tversky. "Prospect Theory: An Analysis of Decision under Risk," Econometrica 47, 1979, 263-292.

Kilian, Lutz. "Exogenous Oil Supply Shocks: How Big Are They and How Much Do They Matter for the U.S. Economy?” Review of Economics and Statistics. 2008, 216-240. (doi: pdf/10.1162/rest.90.2.216)

Katz, Jerome, and Richard Green. Entrepreneurial Small Business, McGraw-Hill, 2010.

Koetse, Mark J., Arno J. van der Vlist and Henri L. F. de Groot, “The Impact of Perceived Expectations and Uncertainty on Firm Investment,” Small Business Economics, 2006, 365-376. (doi: 10.1007/s11187-005-3201-3)

Kennan, John. “The Estimation of Partial Adjustment Models with Rational Expectations,” Econometrica, 1979. 1441-1455. (doi: 10.2307/1914011)

Kulatilaka, Nalin and Enrico C. Perotti. “Strategic Growth Options,” Management Science, 1998, 1021-1031. (doi: 10.1287/mnsc.44.8.1021)

Leduc, Sylvain and Zheng Liu. “Uncertainty, Unemployment, and Inflation,” 2012, Federal Reserve Bank of San Francisco.

Lensink, Robert, Hong Bo and Elmer Sterken. Investment, Capital Market Imperfections, and Uncertainty: Theory and Empirical Results. Edgar Elgar, 2001.

Lensink, Robert, Paul van Steen and Elmer Sterken. "Uncertainty and Growth of the Firm," Small Business Economics, 2005, 381-391. (doi: 10.1007/s11187-005-7121-z)

Levy, Moshe, and Haim Levy. "Prospect Theory: Much Ado about Nothing,” Management Science, 2002, 1334. (doi: 10.1287/mnsc.48.10.1334.276)

Li, Dan. “Multilateral R\&D Alliances by New Ventures,” Journal of Business Venturing, 2013, 241-260. (doi: 10.1016/j.jbusvent.2012.02.004)

Li, Yong. "Duration Analysis of Venture Capital Staging: A Real Options Perspective,” Journal of Business Venturing, 2008, 497-512. (doi: 10.1016/j.jbusvent.2007.10.004)

Li, Yong, Joseph T. Mahoney "When are Venture Capital Projects Initiated?” Journal of Business Venturing, 2011, 239-254. (doi: 10.1016/j.jbusvent.2009.08.001)

Lucas, Robert E. “Asset Prices in an Exchange Economy,” Econometrica 46, 1976, 1429-1445. (doi: 10.2307/1913837)

Marcellino, Massimiliano, James Stock and Mark Watson. "Macroeconomic Forecasting in the Euro Area: Country Specific versus Euro Wide Information,” European Economic 
Review, 2003, 1-18. (doi: 10.1016/S0014-2921(02)00206-4)

McDonald, Robert and Daniel Siegel. “The Value of Waiting to Invest,” Quarterly Journal of Economics 101, 1986, 707-728. (doi: 10.2307/1884175)

Meese, Richard, and John Geweke. "A Comparison of Autoregressive Univariate Forecasting Procedures for Macroeconomic Time Series,” Journal of Business and Economic Statistics, 1984, 191-200. (doi: 10.2307/1391702)

Mishkin, Frederic S. "Over the Cliff: From the Subprime to the Global Financial Crisis.” Journal of Economic Perspectives, 2011, 49-70. (doi: 10.1257/jep.25.1.49)

National Economic Council. "The Small Business Agenda: Growing America’s Small Businesses to Win the Future,” 2011.

Nickell, Stephen J. “Dynamic Models of Labour Demand.” In O.Ashenfelter and R.Layard (Eds.), Handbook of Labor Economics, Volume 1, Chapter 9, 1986, 473-522. Elsevier Science Publishers. (doi: 10.1016/S1573-4463(86)01012-X)

Oi, Walter Y. (1962). “Labor as a Quasi-Fixed Factor,” Journal of Political Economy 70, 538555. (doi: 10.1086/258715)

Oriani, Raffaele. "Technology Switching Option and the Market Value of the Firm: A Model and an Empirical Test,” Advances in Strategic Management 24, 2007, 429-458. (doi:

$10.2139 /$ ssrn.763544)

Oriani, Raffaele, and Maurizio Sobrero. "Uncertainty and the Market Valuation of R\&D within a Real Options Logic,” Strategic Management Journal, 2008, 343-361. (doi: 10.1002/smj.664)

Pindyck, Robert. "Investments of Uncertain Cost,” Journal of Financial Economics 34, 1993, 53-76. (doi: 10.1016/0304-405X(93)90040-I)

Podoynitsyna, Ksenia, Michael Song, Hans van der Bij and Mathieu Weggeman. "Improving New Technology Venture Performance under Direct and Indirect Network Externality Conditions,” Journal of Business Venturing, 2013 195-210. (doi: 0.1016/j.jbusvent.2012.04.004)

Sandmo, Agnar. "On the Theory of the Competitive Firm under Price Uncertainty," American Economic Review 61, 1971, 65-73.

Saemundsson, Rognvaldur, and Asa Lindholm Dahlstrand. "How Business Opportunities Constrain Young Technology-Based Firms from Growing into Medium-Sized Firms,” Small Business Economics, 2005, 113-129. (doi: 10.1007/s11187-003-3803-6)

Sargent, Thomas. "Estimation of Dynamic Labor Demand Schedules under Rational Expectations,” Journal of Political Economy 86, 1978, 1009-1044 (doi: 10.1086/260726) 
Schmitt, John, and Nathan Lane "An International Comparison of Small Business Employment," Center for Economic and Policy Research (CEPR) Reports and Issue Briefs, 2009.

Sheets, Nathan, and Robert Sockin. "Does Size Really Matter?: The Evolving Role of Small Firms in the U.S. Economy,” Empirical \& Thematic Perspectives, Citi Research, 2012.

Stein, Luke, and Elizabeth Stone. "The Effect of Uncertainty on Investment: Evidence from Options,” Stanford University Working Paper, 2010. (doi: 10.2139/ssrn.1649108)

Sutton, John. “Gibrat’s Legacy,” Journal of Economic Literature, 1997, 40-59.

U.S. Small Business Administration. Advocacy: The Voice of Small Business in Government. “Frequently Asked Questions about Small Business Finance,” XXXXXX

Winker, Peter. "Causes and Effects of Financing Constraints at the Firm Level," Small Business Economics, 1999, 169-181. (doi: 10.1023/A:1008035826914) 


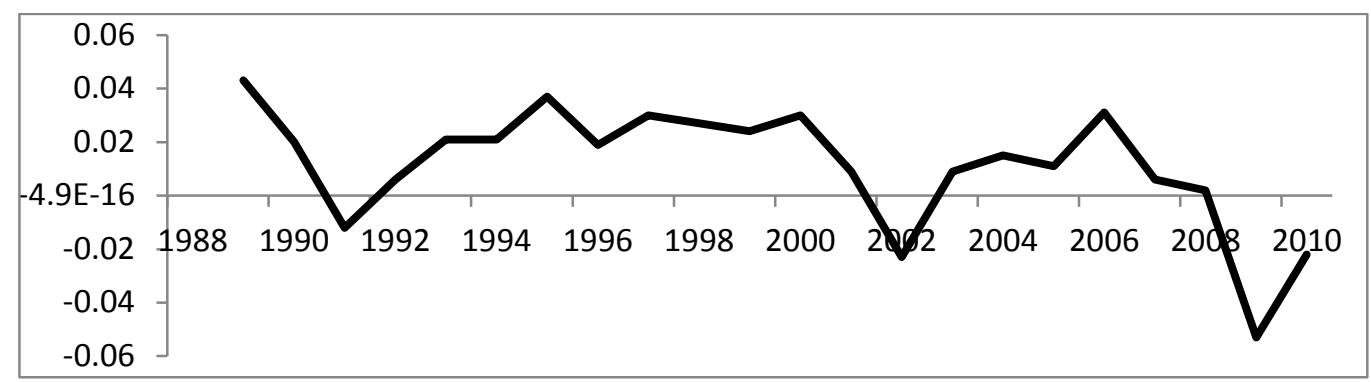

Figure 1.1. Growth of total employment

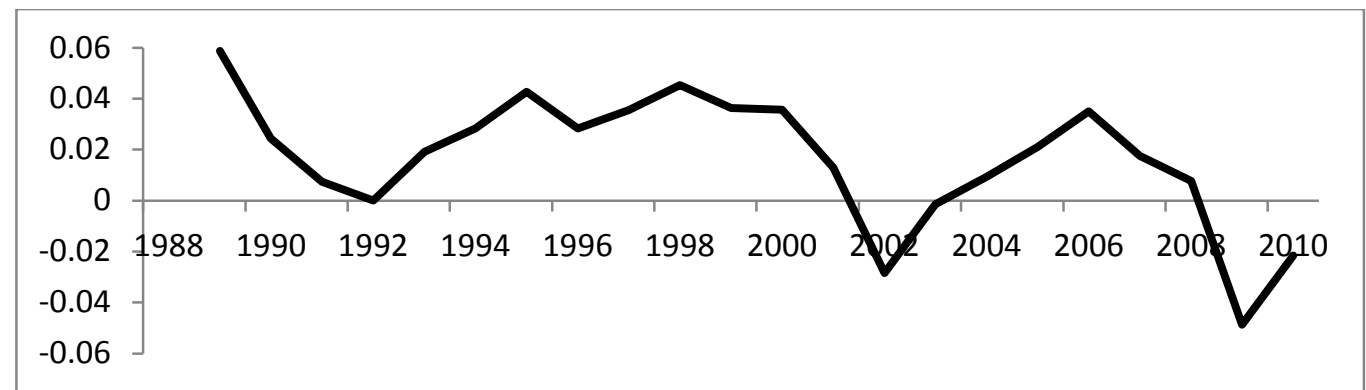

Figure 1.2. Growth of employment in large ( $\geq 500$ employees) businesses

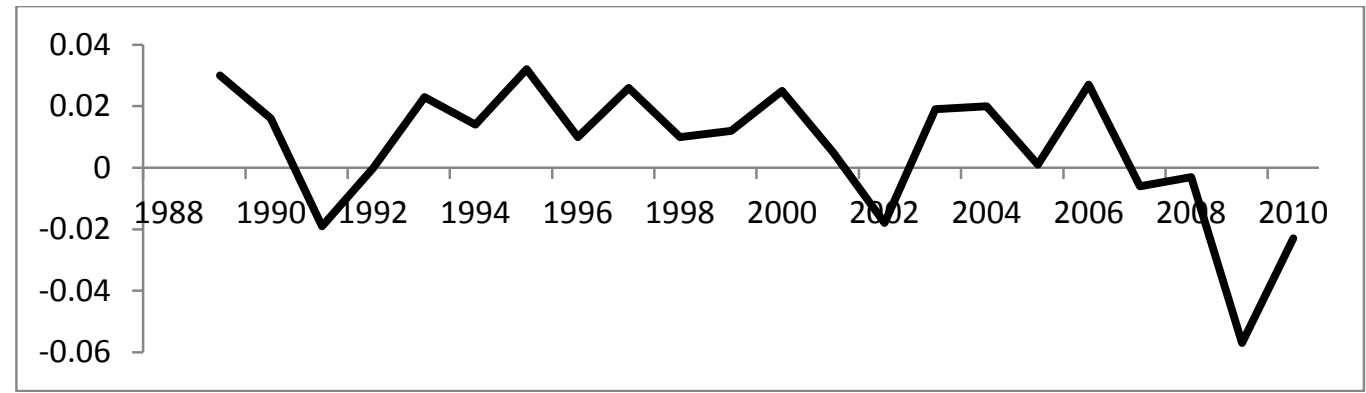

Figure 1.3. Growth of employment in small ( $<500$ employees) businesses

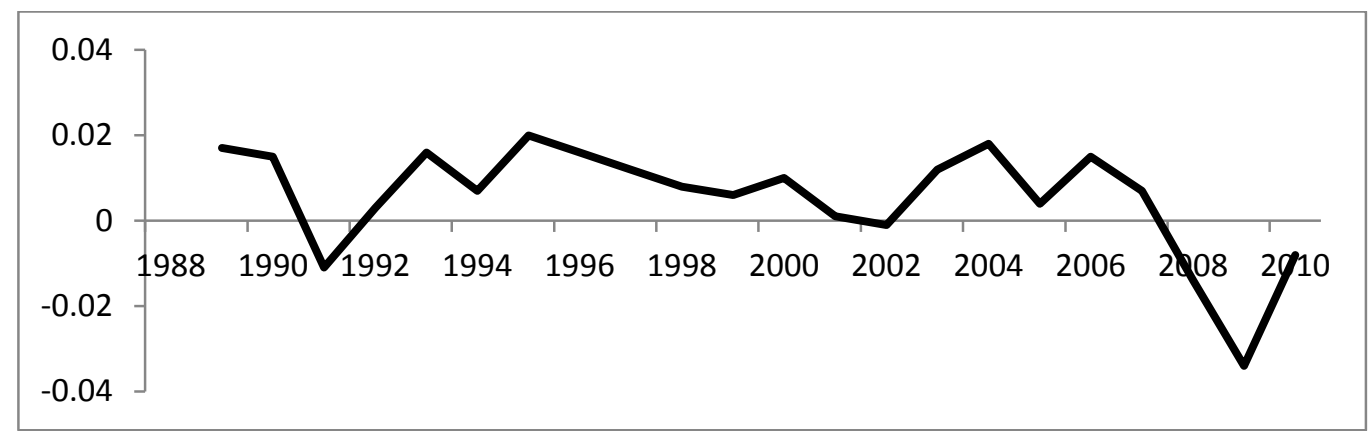

Figure 1.4. Growth of employment in small ( $<20$ employees) businesses 


\begin{tabular}{|c|c|c|c|}
\hline Variable & Mean & Std. Dev. & C.V. \\
\hline \multicolumn{4}{|l|}{ 1. Growth of Employment } \\
\hline $\begin{array}{r}\text { EMP } \\
\text { Size: All }\end{array}$ & 0.01103 & 0.02258 & 204.7 \\
\hline $\begin{array}{r}\text { EMP } \\
\text { Size: Large } w \geq 500 \text { employees }\end{array}$ & 0.01615 & 0.02537 & 157.1 \\
\hline $\begin{array}{r}\text { EMP } \\
\text { Size: Small } w<500 \text { employees }\end{array}$ & 0.00626 & 0.02158 & 344.7 \\
\hline $\begin{array}{r}\text { EMP } \\
\text { Size: Small } w<20 \text { employees }\end{array}$ & 0.00527 & 0.01281 & 243.1 \\
\hline 2. Growth of Real GDP & 0.02550 & 0.01814 & 71.1 \\
\hline \multicolumn{4}{|l|}{ 3. Uncertainty Measures } \\
\hline$\sigma_{s p f g d p, t}^{2}$ & 0.17861 & 0.25266 & 141.4 \\
\hline$\sigma_{\text {spfind }, t}^{2}$ & 0.51206 & 0.73873 & 144.2 \\
\hline$\sigma_{g d p, t}^{2}$ & 0.00027 & 0.00052 & 192.6 \\
\hline$\sigma_{\text {infl,t }}^{2}$ & 0.00003 & 0.00005 & 166.7 \\
\hline$\sigma_{S P 500, t}^{2}$ & 0.01836 & 0.01920 & 104.6 \\
\hline$\sigma_{\text {fuel }, t}^{2}$ & 0.00842 & 0.01281 & 152.1 \\
\hline
\end{tabular}

Notes:

1. C.V. denotes coefficient of variation (percent).

2. The uncertainty variables are:

$$
\begin{aligned}
& \text { (a) Survey of Professional Forecasters (SPF) uncertainty measures } \\
& \sigma_{s p f g d p, t}^{2}=\text { survey of professional forecasters variance of GDP } \\
& \sigma_{\text {spfind }, t}^{2}=\text { survey of professional forecasters variance of industrial (manufacturing) production } \\
& \text { (b) Forecasting-regression generated uncertainty measures } \\
& \sigma_{g d p, t}^{2} \quad=\text { GDP uncertainty } \\
& \sigma_{\text {infl,t }}^{2} \quad=\text { inflation uncertainty } \\
& \sigma_{s p 500, t}^{2}=\mathrm{S} \& \mathrm{P} 500 \text { uncertainty } \\
& \sigma_{f u e l, t}^{2} \quad=\text { fuel price uncertainty }
\end{aligned}
$$

\begin{tabular}{|c|c|c|c|c|c|c|}
\hline & $\sigma_{s p f g d p, t}^{2}$ & $\sigma_{\text {spfind }, t}^{2}$ & $\sigma_{g d p, t}^{2}$ & $\sigma_{\text {infl,t }}^{2}$ & $\sigma_{S P 500, t}^{2}$ & $\sigma_{\text {fuel }, t}^{2}$ \\
\hline$\sigma_{s p f g d p, t}^{2}$ & 1.0000 & $\begin{array}{r}0.6543 \\
(0.001) \\
\end{array}$ & $\begin{array}{r}0.7510 \\
(0.001) \\
\end{array}$ & $\begin{array}{r}0.4144 \\
(0.044) \\
\end{array}$ & $\begin{array}{r}0.4083 \\
(0.048) \\
\end{array}$ & $\begin{array}{l}0.4381 \\
(0.032) \\
\end{array}$ \\
\hline$\sigma_{\text {spfind }, t}^{2}$ & $\begin{array}{r}0.6543 \\
(0.001) \\
\end{array}$ & 1.0000 & $\begin{array}{r}0.7772 \\
(0.001) \\
\end{array}$ & $\begin{array}{r}0.6002 \\
(0.002) \\
\end{array}$ & $\begin{array}{l}0.4559 \\
(0.025)\end{array}$ & $\begin{array}{c}0.6358 \\
(0.001) \\
\end{array}$ \\
\hline$\sigma_{g d p, t}^{2}$ & $\begin{array}{r}0.7510 \\
(0.001) \\
\end{array}$ & $\begin{array}{r}0.7772 \\
(0.001) \\
\end{array}$ & 1.0000 & $\begin{array}{r}0.6941 \\
(0.001) \\
\end{array}$ & $\begin{array}{l}0.5501 \\
(0.005) \\
\end{array}$ & $\begin{array}{r}0.6934 \\
(0.001) \\
\end{array}$ \\
\hline$\sigma_{\text {infl,t }}^{2}$ & $\begin{array}{r}0.4144 \\
(0.044) \\
\end{array}$ & $\begin{array}{r}0.6002 \\
(0.002) \\
\end{array}$ & $\begin{array}{l}0.6941 \\
(0.001) \\
\end{array}$ & 1.00000 & $\begin{array}{r}0.4047 \\
(0.050) \\
\end{array}$ & $\begin{array}{r}0.6288 \\
(0.001) \\
\end{array}$ \\
\hline$\sigma_{S P 500, t}^{2}$ & $\begin{array}{r}0.4083 \\
(0.048)\end{array}$ & $\begin{array}{r}0.4559 \\
(0.025) \\
\end{array}$ & $\begin{array}{c}0.5501 \\
(0.005)\end{array}$ & $\begin{array}{r}0.4047 \\
(0.050) \\
\end{array}$ & 1.0000 & $\begin{array}{c}0.3688 \\
(0.076)\end{array}$ \\
\hline$\sigma_{\text {fuel }, t}^{2}$ & $\begin{array}{r}0.4381 \\
(0.032) \\
\end{array}$ & $\begin{array}{r}0.6358 \\
(0.001) \\
\end{array}$ & $\begin{array}{r}0.6934 \\
(0.0002) \\
\end{array}$ & $\begin{array}{r}0.6288 \\
(0.001) \\
\end{array}$ & $\begin{array}{l}0.3688 \\
(0.076) \\
\end{array}$ & 1.0000 \\
\hline
\end{tabular}

Notes: The $p$-values are reported in parentheses. 


\begin{tabular}{|c|c|c|c|c|c|c|c|c|c|c|c|c|}
\hline & \multicolumn{6}{|c|}{ Size Group: All Businesses } & \multicolumn{6}{|c|}{$\underline{\text { Size Group: Large ( } \geq 500 \text { Employee) Businesses }}$} \\
\hline & S1 & S2 & S3 & S4 & S5 & S6 & S1 & $\mathrm{S} 2$ & S3 & S4 & S5 & S6 \\
\hline Const. & $\begin{array}{r}-0.0264^{*} \\
(0.001)\end{array}$ & $\begin{array}{r}-0.0273^{*} \\
(0.001)\end{array}$ & $\begin{array}{r}-0.0239 * \\
(0.087)\end{array}$ & $\begin{array}{r}-0.0486^{*} \\
(0.023)\end{array}$ & $\begin{array}{r}-0.0314^{*} \\
(0.001)\end{array}$ & $\begin{array}{r}-0.0493^{*} \\
(0.001)\end{array}$ & $\begin{array}{r}-0.0183 * \\
(0.055)\end{array}$ & $\begin{array}{r}-0.0197 * \\
(0.001)\end{array}$ & $\begin{array}{r}-0.0087 \\
(0.653)\end{array}$ & $\begin{array}{r}-0.0555^{*} \\
(0.048)\end{array}$ & $\begin{array}{r}-0.0243^{*} \\
(0.013)\end{array}$ & $\begin{array}{r}-0.0382 * \\
(0.001)\end{array}$ \\
\hline$E M P_{t-1}$ & $\begin{array}{c}-0.2261 \\
(0.122)\end{array}$ & $\begin{array}{r}-0.3510^{*} \\
(0.070)\end{array}$ & $\begin{array}{r}-0.3517^{*} \\
(0.034)\end{array}$ & $\begin{array}{r}-0.4135^{*} \\
(0.048)\end{array}$ & $\begin{array}{r}-0.2208 \\
(0.128)\end{array}$ & $\begin{array}{c}-0.4797 * \\
(0.0142)\end{array}$ & $\begin{array}{r}0.1390 \\
(0.202)\end{array}$ & $\begin{array}{r}0.1867^{*} \\
(0.038)\end{array}$ & $\begin{array}{r}-0.0015 \\
(0.992)\end{array}$ & $\begin{array}{c}0.1216 \\
(0.204)\end{array}$ & $\begin{array}{r}0.1703^{*} \\
(0.041)\end{array}$ & $\begin{array}{l}0.0185 \\
(0.869)\end{array}$ \\
\hline$E M P_{t-2}$ & - & - & - & - & - & - & - & - & - & - & - & - \\
\hline$G D P_{t}$ & $\begin{array}{r}0.5624^{*} \\
(0.006)\end{array}$ & $\begin{array}{r}0.5110 * \\
(0.001)\end{array}$ & $\begin{array}{r}0.6924^{*} \\
(0.001)\end{array}$ & $\begin{array}{r}0.5858^{*} \\
(0.001)\end{array}$ & $\begin{array}{r}0.5854 * \\
(0.001)\end{array}$ & $\begin{array}{r}0.4492 * \\
(0.001)\end{array}$ & $\begin{array}{r}0.6119 * \\
(0.009)\end{array}$ & $\begin{array}{r}0.5776^{*} \\
(0.001)\end{array}$ & $\begin{array}{r}0.7452 * \\
(0.000)\end{array}$ & $\begin{array}{r}0.5833 * \\
(0.001)\end{array}$ & $\begin{array}{r}0.6129 * \\
(0.001)\end{array}$ & $\begin{array}{r}0.5121 * \\
(0.001)\end{array}$ \\
\hline$G D P_{t-1}$ & $\begin{array}{r}0.7489 * \\
(0.002)\end{array}$ & $\begin{array}{r}0.8648^{*} \\
(0.001)\end{array}$ & $\begin{array}{r}0.8168^{*} \\
(0.002)\end{array}$ & $\begin{array}{r}0.9315^{*} \\
(0.001)\end{array}$ & $\begin{array}{r}0.7659^{*} \\
(0.001)\end{array}$ & $\begin{array}{r}0.9676^{*} \\
(0.001)\end{array}$ & $\begin{array}{r}0.6213^{*} \\
(0.002)\end{array}$ & $\begin{array}{r}0.5711^{*} \\
(0.005)\end{array}$ & $\begin{array}{r}0.6656^{*} \\
(0.003)\end{array}$ & $\begin{array}{r}0.5516^{*} \\
(0.010)\end{array}$ & $\begin{array}{r}0.5674^{*} \\
(0.003)\end{array}$ & $\begin{array}{r}0.6839 * \\
(0.002)\end{array}$ \\
\hline$\sigma_{s p f g d p, t}^{2}$ & $\begin{array}{l}0.0002 \\
(0.950)\end{array}$ & - & - & - & - & - & $\begin{array}{l}0.0010 \\
(0.799)\end{array}$ & - & - & - & - & - \\
\hline$\sigma_{s p f g d p, t-1}^{2}$ & $\begin{array}{r}-0.0025 \\
(0.112)\end{array}$ & - & - & - & - & - & $\begin{array}{l}-0.0008 \\
(0.696)\end{array}$ & - & - & - & - & - \\
\hline$\sigma_{\text {spfind }, t}^{2}$ & - & $\begin{array}{r}-0.0017 \\
(0.221)\end{array}$ & - & - & - & - & - & $\begin{array}{l}-0.0019 \\
(0.237)\end{array}$ & - & - & - & - \\
\hline$\sigma_{\text {spfind }, t-1}^{2}$ & - & $\begin{array}{l}-0.0017 \\
(0.262)\end{array}$ & - & - & - & - & - & $\begin{array}{l}0.0009 \\
(0.613)\end{array}$ & - & - & - & - \\
\hline$\sigma_{g d p, t}^{2}$ & - & - & $\begin{array}{r}0.0030^{*} \\
(0.063)\end{array}$ & - & - & - & - & - & $\begin{array}{l}0.0042 \\
(0.125)\end{array}$ & - & - & - \\
\hline$\sigma_{g d p, t-1}^{2}$ & - & - & $\begin{array}{r}-0.0032^{*} \\
(0.049)\end{array}$ & - & - & - & - & - & $\begin{array}{r}-0.0028 \\
(0.178)\end{array}$ & - & - & - \\
\hline$\sigma_{i n f l, t}^{2}$ & - & - & - & $\begin{array}{l}0.0004 \\
(0.795)\end{array}$ & - & - & - & - & - & $\begin{array}{r}-0.0015 \\
(0.465)\end{array}$ & - & - \\
\hline$\sigma_{\text {infl,t-1 }}^{2}$ & - & - & - & $\begin{array}{r}-0.0026^{*} \\
(0.027)\end{array}$ & - & - & - & - & - & $\begin{array}{r}-0.0020^{*} \\
(0.091)\end{array}$ & - & - \\
\hline$\sigma_{s p 500, t}^{2}$ & - & - & - & - & $\begin{array}{r}-0.0004 \\
(0.541)\end{array}$ & - & - & - & - & - & $\begin{array}{l}0.0001 \\
(0.903)\end{array}$ & - \\
\hline$\sigma_{s p 500, t-1}^{2}$ & - & - & - & - & $\begin{array}{r}-0.0014^{*} \\
(0.099)\end{array}$ & - & - & - & - & - & $\begin{array}{r}-0.0013 \\
(0.158)\end{array}$ & - \\
\hline$\sigma_{\text {fuel }, t}^{2}$ & - & - & - & - & - & $\begin{array}{r}-0.0038^{*} \\
(0.002)\end{array}$ & - & - & - & - & - & $\begin{array}{r}-0.0026^{*} \\
(0.081)\end{array}$ \\
\hline$\sigma_{\text {fuel }, t-1}^{2}$ & - & - & - & - & - & $\begin{array}{l}-0.0017 \\
(0.150)\end{array}$ & - & - & - & - & - & $\begin{array}{r}-0.0017 \\
(0.159)\end{array}$ \\
\hline $\bar{R}^{2}$ & 0.806 & 0.825 & 0.833 & 0.819 & 0.819 & 0.882 & 0.752 & 0.764 & 0.798 & 0.770 & 0.762 & 0.789 \\
\hline$\rho$ & 0.177 & 0.225 & 0.147 & 0.264 & 0.036 & -0.133 & 0.144 & 0.113 & 0.051 & 0.158 & 0.079 & -0.067 \\
\hline
\end{tabular}

1. $p$-values (two-tailed test) based on efficient standard errors are reported in parentheses. An * denotes significance at least at the $10 \%$ level. All specifications are estimated using annual observations over the period 1988-2011 (data details are presented in section 4). 
2. The first-order autocorrelation coefficient is denoted by $\rho$.

3. The variable definitions are as follows.

$E M P_{t} \quad=$ Growth (annual percentage change) of employment

$G D P_{t} \quad=$ Growth (annual percentage change) of real GDP

Survey of Professional Forecasters (SPF) uncertainty measures

$\sigma_{s p f g d p, t}^{2}=$ survey of professional forecasters variance of GDP

$\sigma_{\text {spfind,t }}^{2} \quad=$ survey of professional forecasters variance of industrial (manufacturing) production

Estimation generated uncertainty measures

$\sigma_{g d p, t}^{2} \quad=$ GDP uncertainty

$\sigma_{\text {infl,t }}^{2} \quad=$ inflation uncertainty

$\sigma_{s p 500, t}^{2} \quad=$ S\&P 500 uncertainty

$\sigma_{f u e l, t}^{2} \quad=$ fuel price uncertainty

4. As noted in section 5, the uncertainty terms are measured in natural logarithms. 


\begin{tabular}{|c|c|c|c|c|c|c|c|c|c|c|c|c|}
\hline & \multicolumn{6}{|c|}{ Size Group: Small (<500 Employee) Businesses } & \multicolumn{6}{|c|}{ Size Group: Small (<20 Employee) Businesses } \\
\hline & S1 & S2 & S3 & S4 & S5 & S6 & S1 & $\mathrm{S} 2$ & S3 & S4 & S5 & S6 \\
\hline Const. & $\begin{array}{r}-0.0359 * \\
(0.001)\end{array}$ & $\begin{array}{r}-0.0346^{*} \\
(0.001)\end{array}$ & $\begin{array}{r}-0.0563^{*} \\
(0.001) \\
\end{array}$ & $\begin{array}{r}-0.0687 * \\
(0.016) \\
\end{array}$ & $\begin{array}{r}-0.0370^{*} \\
(0.001) \\
\end{array}$ & $\begin{array}{r}-0.0480^{*} \\
(0.001) \\
\end{array}$ & $\begin{array}{r}-0.0192 * \\
(0.001) \\
\end{array}$ & $\begin{array}{r}-0.0153^{*} \\
(0.001)\end{array}$ & $\begin{array}{r}-0.0384^{*} \\
(0.001)\end{array}$ & $\begin{array}{c}-0.0279 \\
(0.151) \\
\end{array}$ & $\begin{array}{r}-0.0174^{*} \\
(0.001)\end{array}$ & $\begin{array}{r}-0.0221^{*} \\
(0.013)\end{array}$ \\
\hline$E M P_{t-1}$ & $\begin{array}{r}-0.4107^{*} \\
(0.012) \\
\end{array}$ & $\begin{array}{r}-0.5815^{*} \\
(0.002) \\
\end{array}$ & $\begin{array}{r}-0.4837 * \\
(0.007) \\
\end{array}$ & $\begin{array}{r}-0.5318^{*} \\
(0.018) \\
\end{array}$ & $\begin{array}{r}-0.3907^{*} \\
(0.042) \\
\end{array}$ & $\begin{array}{r}-0.5465^{*} \\
(0.004) \\
\end{array}$ & $\begin{array}{r}0.0943 \\
(0.594) \\
\end{array}$ & $\begin{array}{l}-0.0239 \\
(0.873) \\
\end{array}$ & $\begin{array}{r}-0.0322 \\
(0.862) \\
\end{array}$ & $\begin{array}{r}0.1030 \\
(0.637) \\
\end{array}$ & $\begin{array}{r}0.1013 \\
(0.581) \\
\end{array}$ & $\begin{array}{r}0.0136 \\
(0.941) \\
\end{array}$ \\
\hline$E M P_{t-2}$ & - & - & - & - & - & - & $\begin{array}{r}-0.2844^{*} \\
(0.084)\end{array}$ & - & - & - & - & $\begin{array}{r}-0.2754^{*} \\
(0.013)\end{array}$ \\
\hline$G D P_{t}$ & $\begin{array}{r}0.4495^{*} \\
(0.046)\end{array}$ & $\begin{array}{r}0.4492 * \\
(0.001)\end{array}$ & $\begin{array}{r}0.5554^{*} \\
(0.002)\end{array}$ & $\begin{array}{r}0.5503^{*} \\
(0.001)\end{array}$ & $\begin{array}{r}0.5806^{*} \\
(0.001)\end{array}$ & $\begin{array}{r}0.4363^{*} \\
(0.001)\end{array}$ & $\begin{array}{r}0.2969 * \\
(0.007)\end{array}$ & $\begin{array}{r}0.4223 * \\
(0.001)\end{array}$ & $\begin{array}{r}0.3990^{*} \\
(0.001)\end{array}$ & $\begin{array}{r}0.4519 * \\
(0.001)\end{array}$ & $\begin{array}{c}0.4792 * \\
(0.001)\end{array}$ & $\begin{array}{r}0.3781^{*} \\
(0.001)\end{array}$ \\
\hline$G D P_{t-1}$ & $\begin{array}{r}0.7867 * \\
(0.001)\end{array}$ & $\begin{array}{l}0.8903 \\
(0.001)\end{array}$ & $\begin{array}{r}0.7612^{*} \\
(0.003)\end{array}$ & $\begin{array}{r}0.8475^{*} \\
(0.004)\end{array}$ & $\begin{array}{r}0.7603^{*} \\
(0.003)\end{array}$ & $\begin{array}{r}0.9219^{*} \\
(0.001)\end{array}$ & $\begin{array}{r}0.1232 \\
(0.315)\end{array}$ & $\begin{array}{l}0.0676 \\
(0.532)\end{array}$ & $\begin{array}{l}0.1040 \\
(0.473)\end{array}$ & $\begin{array}{l}0.0551 \\
(0.723)\end{array}$ & $\begin{array}{l}0.0625 \\
(0.671)\end{array}$ & $\begin{array}{r}0.1813 \\
(0.1053)\end{array}$ \\
\hline$\overline{\sigma_{s p f g d p, t}^{2}}$ & $\begin{array}{r}-0.0014 \\
(0.658)\end{array}$ & - & - & - & - & - & $\begin{array}{r}-0.0028^{*} \\
(0.063)\end{array}$ & - & - & - & - & - \\
\hline$\sigma_{s p f g d p, t-1}^{2}$ & $\begin{array}{r}-0.0039^{*} \\
(0.008)\end{array}$ & - & - & - & - & - & $\begin{array}{r}-0.0031^{*} \\
(0.004)\end{array}$ & - & - & - & - & - \\
\hline$\overline{\sigma_{\text {spfind }, t}^{2}}$ & - & $\begin{array}{r}-0.0025^{*} \\
(0.051)\end{array}$ & - & - & - & - & - & $\begin{array}{r}-0.0026 * \\
(0.001)\end{array}$ & - & - & - & - \\
\hline$\sigma_{\text {spfind }, t-1}^{2}$ & - & $\begin{array}{r}-0.0029^{*} \\
(0.014)\end{array}$ & - & - & - & - & - & $\begin{array}{r}-0.0015^{*} \\
(0.039)\end{array}$ & - & - & - & - \\
\hline$\overline{\sigma_{g d p, t}^{2}}$ & - & - & $\begin{array}{l}0.0004 \\
(0.819)\end{array}$ & - & - & - & - & - & $\begin{array}{l}-0.0015 \\
(0.236)\end{array}$ & - & - & - \\
\hline$\sigma_{g d p, t-1}^{2}$ & - & - & $\begin{array}{r}-0.0038^{*} \\
(0.010)\end{array}$ & - & - & - & - & - & $\begin{array}{r}-0.0017^{*} \\
(0.063)\end{array}$ & - & - & - \\
\hline$\sigma_{\text {infl }, t}^{2}$ & - & - & - & $\begin{array}{l}-0.0010 \\
(0.594)\end{array}$ & - & - & - & - & - & $\begin{array}{l}-0.0014 \\
(0.208)\end{array}$ & - & - \\
\hline$\sigma_{\text {infl,t-1 }}^{2}$ & - & - & - & $\begin{array}{r}-0.0027^{*} \\
(0.075)\end{array}$ & - & - & - & - & - & $\begin{array}{r}-0.0003 \\
(0.809)\end{array}$ & - & - \\
\hline$\sigma_{s p 500, t}^{2}$ & - & - & - & - & $\begin{array}{c}-0.0001 \\
(0.861)\end{array}$ & - & - & - & - & - & $\begin{array}{c}-0.0003 \\
(0.562)\end{array}$ & - \\
\hline$\sigma_{s p 500, t-1}^{2}$ & - & - & - & - & $\begin{array}{r}-0.0020^{*} \\
(0.030)\end{array}$ & - & - & - & - & - & $\begin{array}{r}-0.0012 * \\
(0.036)\end{array}$ & - \\
\hline$\sigma_{\text {fuel, }, t}^{2}$ & - & - & - & - & - & $\begin{array}{r}-0.0038^{*} \\
(0.003)\end{array}$ & - & - & - & - & - & $\begin{array}{c}-0.0027^{*} \\
(0.0033)\end{array}$ \\
\hline$\sigma_{\text {fuel }, t-1}^{2}$ & - & - & - & - & - & $\begin{array}{l}-0.0006 \\
(0.692)\end{array}$ & & - & - & - & - & $\begin{array}{l}-0.0001 \\
(0.899)\end{array}$ \\
\hline $\bar{R}^{2}$ & 0.749 & 0.796 & 0.773 & 0.741 & 0.755 & 0.795 & 0.745 & 0.768 & 0.724 & 0.629 & 0.667 & 0.754 \\
\hline$\rho$ & 0.124 & 0.134 & 0.241 & 0.213 & 0.111 & 0.160 & 0.001 & 0.063 & 0.117 & 0.066 & 0.113 & 0.095 \\
\hline
\end{tabular}




\begin{tabular}{|c|c|c|c|c|c|c|c|c|c|c|c|c|}
\hline & & & $\begin{array}{l}\text { Size Group: } \\
\text { growth of }\end{array}$ & $\begin{array}{l}\text { Businesses } \\
\text { oyment }=0 .\end{array}$ & & & & $\frac{\text { Size G }}{1}$ & $\begin{array}{l}\text { Large ( } \geq 5 \\
\text { growth of }\end{array}$ & $\begin{array}{l}\text { mployee) } 1 \\
\text { oyment }=0 \text {. }\end{array}$ & esses & \\
\hline & S1 & S2 & S3 & S4 & S5 & S6 & S1 & S2 & S3 & S4 & S5 & S6 \\
\hline$G D P_{t}$ & $0.0101^{*}$ & $0.0092 *$ & $0.0125 *$ & $0.0105^{*}$ & $0.0105^{*}$ & $0.0081^{*}$ & $0.0110^{*}$ & $0.0104^{*}$ & $0.0134^{*}$ & $0.0105^{*}$ & $0.0110^{*}$ & $0.0092^{*}$ \\
\hline$G D P_{t-1}$ & 0.0135* & $0.0156^{*}$ & $0.0147^{*}$ & 0.0167* & 0.0138* & $0.0174^{*}$ & $0.0112 *$ & 0.0103* & 0.0119* & 0.0099* & $0.0102^{*}$ & $0.0123^{*}$ \\
\hline$\overline{\sigma_{s p f g d p, t}^{2}}$ & 0.0003 & - & - & - & - & - & 0.0014 & - & - & - & - & - \\
\hline$\overline{\sigma_{s p f g d p, t-1}^{2}}$ & -0.0036 & - & - & - & - & - & -0.0011 & - & - & - & - & - \\
\hline$\overline{\sigma_{\text {spfind }, t}^{2}}$ & - & -0.0024 & - & - & - & - & - & -0.0027 & - & - & - & - \\
\hline$\overline{\sigma_{\text {spfind }, t-1}^{2}}$ & - & -0.0023 & - & - & - & - & - & 0.0013 & - & - & - & - \\
\hline$\sigma_{g d p, t}^{2}$ & - & - & $0.0058^{*}$ & - & - & - & - & - & 0.0081 & - & - & - \\
\hline$\sigma_{g d p, t-1}^{2}$ & - & - & $-0.0062 *$ & - & - & - & - & - & -0.0054 & - & - & - \\
\hline$\overline{\sigma_{\text {infl }, t}^{2}}$ & - & - & - & 0.0007 & - & - & - & - & - & -0.0025 & - & - \\
\hline$\sigma_{\text {infl,t-1 }}^{2}$ & - & - & - & $-0.0043^{*}$ & - & - & - & - & - & $-0.0033^{*}$ & - & - \\
\hline$\sigma_{s p 500, t}^{2}$ & - & - & - & - & -0.0004 & - & - & - & - & - & 0.0001 & - \\
\hline$\sigma_{s p 500, t-1}^{2}$ & - & - & - & - & $-0.0015^{*}$ & - & - & - & - & - & -0.0013 & - \\
\hline$\sigma_{\text {fuel, } t}^{2}$ & - & - & - & - & - & $-0.0058^{*}$ & - & - & - & - & - & $-0.0039^{*}$ \\
\hline$\sigma_{\text {fuel, }, t-1}^{2}$ & - & - & - & - & - & -0.0026 & - & - & - & - & - & -0.0026 \\
\hline
\end{tabular}

Notes:

1. The notes for this table are same as for table 3.1. An asterisk denotes that the estimated effect is significant at least at the $10 \%$ level. For each specification's regression statistics $\left(\bar{R}^{2}\right.$ and $\left.\rho\right)$, see table 3.1 .

2. The reported numbers above measure the effect of a one-standard-deviation increase in the relevant independent variable on growth of employment by size category. See section 7.2 for details. 3. To keep the table compact, the effects of lagged dependent variable are not reported. 


\begin{tabular}{|c|c|c|c|c|c|c|c|c|c|c|c|c|}
\hline & & $\frac{\text { Size C }}{1}$ & $\begin{array}{l}\text { oup: Small }(<5 \\
\text { ean growth of }\end{array}$ & $\begin{array}{l}\text { D0 Employee) } \\
\text { mployment }=0\end{array}$ & $\begin{array}{l}\text { Businesses } \\
\underline{0063}\end{array}$ & & & $\frac{\text { Size }}{1}$ & $\begin{array}{l}\text { roup: Small (< } \\
\text { ean growth of }\end{array}$ & $\begin{array}{l}0 \text { Employee) } \mathrm{B} \\
\text { mployment }=0 \text {. }\end{array}$ & $\begin{array}{l}\text { sinesses } \\
053\end{array}$ & \\
\hline & S1 & S2 & S3 & S4 & S5 & S6 & S1 & $\mathrm{S} 2$ & S3 & S4 & S5 & S6 \\
\hline$\overline{G D P_{t}}$ & $0.0081^{*}$ & $0.0081^{*}$ & 0.0099* & $0.0098^{*}$ & $0.0104 *$ & $0.0078^{*}$ & $0.0053^{*}$ & $0.0076^{*}$ & $0.0072^{*}$ & $0.0082^{*}$ & 0.0086* & $0.0068^{*}$ \\
\hline$G D P_{t-1}$ & $0.0142 *$ & 0.0160 & $0.0137^{*}$ & $0.0152 *$ & $0.0137^{*}$ & $0.0166^{*}$ & 0.0022 & 0.0012 & 0.0018 & 0.0009 & 0.0011 & 0.0033 \\
\hline$\overline{\sigma_{s p f g d p, t}^{2}}$ & -0.0019 & - & - & - & - & - & $-0.0039 *$ & - & - & - & - & - \\
\hline$\sigma_{s p f g d p, t-1}^{2}$ & $-0.0051^{*}$ & - & - & - & - & - & $-0.0044^{*}$ & - & - & - & - & - \\
\hline$\overline{\sigma_{\text {spfind }, t}^{2}}$ & - & $-0.0036^{*}$ & - & - & - & - & - & $-0.0037^{*}$ & - & - & - & - \\
\hline$\sigma_{\text {spfind }, t-1}^{2}$ & - & $-0.0042^{*}$ & - & - & - & - & - & $-0.0021^{*}$ & - & - & - & - \\
\hline$\sigma_{g d p, t}^{2}$ & - & - & 0.0008 & - & - & - & - & - & -0.0029 & - & - & - \\
\hline$\sigma_{g d p, t-1}^{2}$ & - & - & $-0.0074^{*}$ & - & - & - & - & - & $-0.0033^{*}$ & - & - & - \\
\hline$\sigma_{i n f l, t}^{2}$ & - & - & - & -0.0017 & - & - & - & - & - & -0.0023 & - & - \\
\hline$\sigma_{\text {infl }, t-1}^{2}$ & - & - & - & $-0.0045^{*}$ & - & - & - & - & - & -0.0005 & - & - \\
\hline$\sigma_{s p 500, t}^{2}$ & - & - & - & - & -0.0001 & - & - & - & - & - & $\begin{array}{l}-0.0003 \\
\end{array}$ & - \\
\hline$\overline{\sigma_{s p 500, t-1}^{2}}$ & - & - & - & - & $-0.0021^{*}$ & - & - & - & - & - & $-0.0012^{*}$ & - \\
\hline$\sigma_{\text {fuel, }, t}^{2}$ & - & - & - & - & - & $\begin{array}{l}-0.0058^{*} \\
\end{array}$ & - & - & - & - & - & $-0.0041^{*}$ \\
\hline$\sigma_{\text {fuel }, t-1}^{2}$ & - & - & - & - & - & -0.0009 & & - & - & - & - & -0.0001 \\
\hline
\end{tabular}

Notes:

1. The notes for this table are same as for table 3.2; an asterisk denotes that the estimated effect is significant at least at the $10 \%$ level. For each specification's regression statistics $\left(\bar{R}^{2}\right.$ and $\left.\rho\right)$, see table

3.2.

2. The reported numbers above measure the effect of a one-standard-deviation increase in the relevant independent variable on growth of employment by size category. See section 7.2 for details.
3. To keep the table compact, the effects of lagged dependent variable are not reported. 


\begin{tabular}{|c|c|c|c|c|c|c|c|c|}
\hline Size & $\sigma_{s p f g d p}^{2}$ & $\overline{\sigma_{\text {spfind }}^{2}}$ & $\sigma_{g d p}^{2}$ & $\sigma_{i n f l}^{2}$ & $\sigma_{s p 500}^{2}$ & $\sigma_{\text {fuel }}^{2}$ & $\overline{\overline{\sigma^{2}}}$ & $\overline{\overline{G D P}}$ \\
\hline $\begin{array}{l}\text { All } \\
\bar{E}=0.0110\end{array}$ & 0 & 0 & $-0.0040 *$ & $-0.0043 *$ & $-0.0015^{*}$ & $-0.0058 *$ & -0.0026 & 0.0255 \\
\hline $\begin{array}{l}\text { Large }(>500) \\
\bar{E}=0.0161\end{array}$ & 0 & 0 & 0 & $-0.0033^{*}$ & 0 & $-0.0039 *$ & -0.0012 & 0.0225 \\
\hline $\begin{array}{l}\text { Small }(<500) \\
\bar{E}=0.0063\end{array}$ & $-0.0051^{*}$ & $-0.0078 *$ & $-0.0074 *$ & $-0.0045^{*}$ & $-0.0021^{*}$ & $-0.0058 *$ & -0.0055 & 0.0230 \\
\hline $\begin{array}{l}\text { Smaller }(<20) \\
\bar{E}=0.0053\end{array}$ & $-0.0083^{*}$ & $-0.0058^{*}$ & $-0.0033^{*}$ & 0 & $-0.0012^{*}$ & $-0.0041^{*}$ & -0.0037 & 0.0075 \\
\hline
\end{tabular}

Notes:

1. From tables 4.1 and 4.2, we take the sum of the significant coefficients of each effect (e.g., $\sigma_{\text {spfgdp }}^{2}$ ); these are the reported numbers above in each cell. If a particular coefficient is not statistically significant at the $10 \%$ level, we impute a value of zero for the above table.

2. $\bar{E}$ is the mean growth (annual percentage change) of employment, by size category.

3. The term $\overline{\sigma^{2}}$ is the average uncertainty effect, across the different measures. The term $\overline{G D P}$ is the average GDP effect, across the different specifications. 